\title{
Arc Basalt Simulator version 2, a simulation for slab dehydration and fluid-fluxed mantle melting for arc basalts: Modeling scheme and application
}

\section{Jun-Ichi Kimura}

Institute for Research on Earth Evolution, Japan Agency for Marine-Earth Science and Technology, Yokosuka 237-0061, Japan (jkimura@jamstec.go.jp)

\section{Bradley R. Hacker}

Department of Earth Science, University of California, Santa Barbara, California 93106-9630, USA (backer@geol.ucsb.edu)

\section{Peter E. van Keken}

Department of Geological Sciences, University of Michigan, 1100 North University Avenue, Ann Arbor, Michigan 48109-1005, USA (keken@umich.edu)

\section{Hiroshi Kawabata}

Institute for Research on Earth Evolution, Japan Agency for Marine-Earth Science and Technology, Yokosuka 2370061, Japan (biroshik@jamstec.go.jp)

\section{Takeyoshi Yoshida}

Institute of Mineralogy Petrology and Economic Geology, Tohoku University, Sendai 980-8578, Japan (tyoshida@mail.tains.tohoku.ac.jp)

\section{Robert J. Stern}

Department of Geosciences, University of Texas at Dallas, Richardson, Texas 75083-0688, USA (rjstern@utdallas.edu)

[1] Convergent margin magmas typically have geochemical signatures that include elevated concentrations of large-ion lithophile elements; depleted heavy rare earth elements and high field strength elements; and variously radiogenic $\mathrm{Sr}, \mathrm{Pb}$, and $\mathrm{Nd}$ isotopic compositions. These have been attributed to the melting of depleted mantle peridotite by the fluxing of fluids or melts derived from subducting oceanic crust. High $\mathrm{Mg}$ \# basalts and high $\mathrm{Mg} \#$ andesites are inferred to make up the bulk of subduction-related primary magmas and may be generated by fluid or melt fluxing of mantle peridotite. The difference in contributions from the subducted slab found among various arcs appears to be mostly controlled by thermal structure. Cold slabs yield fluids, and hot slabs yield melts. Recent experimental studies and thermodynamic models better constrain the phase petrology of the slab components during prograde metamorphism and melting, mantle wedge melting, and mantle slab melt reaction. Experimental results also constrain the behavior of many elements in these processes. In addition, geodynamic models allow increasingly realistic, quantitative modeling of the temperature and pressure in the subducted slab and mantle wedge. These developments together enable generation of forward models to explain arc magma geochemistry. The Arc

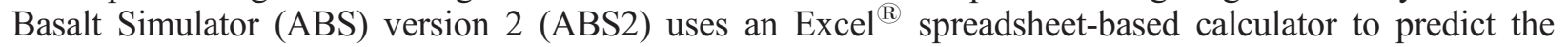
partitioning of incompatible element and $\mathrm{Sr}-\mathrm{Nd}-\mathrm{Pb}$ isotopic composition in a slab-derived fluid and in arc basalt magma generated by an open system fluid-fluxed melting of mantle wedge peridotite. The ABS2 
model is intended to simulate high $\mathrm{Mg}$ \# basalt geochemistry in relatively cold subduction zones. The modeling scheme of ABS2 is presented and is applied to primitive arc magmas.

Components: 20,276 words, 7 figures.

Keywords: arc basalt; fluid; partial melting; subduction.

Index Terms: 3620 Mineralogy and Petrology: Mineral and crystal chemistry (1042); 8439 Volcanology: Physics and chemistry of magma bodies; 1749 History of Geophysics: Volcanology, geochemistry, and petrology.

Received 27 August 2008; Revised 18 June 2009; Accepted 1 July 2009; Published 16 September 2009.

Kimura, J.-I., B. R. Hacker, P. E. van Keken, H. Kawabata, T. Yoshida, and R. J. Stern (2009), Arc Basalt Simulator version 2 , a simulation for slab dehydration and fluid-fluxed mantle melting for arc basalts: Modeling scheme and application, Geochem. Geophys. Geosyst., 10, Q09004, doi:10.1029/2008GC002217.

\section{Introduction}

\subsection{Arc Magmatism}

[2] Convergent margin magmatism has been intensively studied using trace element and radiogenic isotope geochemistry. The fundamental control on element partitioning in most arc magmas is believed to originate during the extraction of fluids and/or melts (flux) from the subducted slab, and subsequent flux melting of the mantle wedge to generate high $\mathrm{Mg}$ \# primitive arc basalts [Arculus and Johnson, 1981; Davidson, 1996; Elliott et al., 1997; Hawkesworth et al., 1993; Kelemen et al., 1998; Kimura and Yoshida, 2006; Plank and Langmuir, 1993; Poli and Schmidt, 1995; Stern, 2002; Stolper and Newman, 1994; Tatsumi and Eggins, 1995; Turner et al., 1997], or by slab melt-mantle reaction to generate high $\mathrm{Mg}$ \# primitive arc andesites [Kelemen et al., 2003b; Tatsumi and Hanyu, 2003; Tsuchiya et al., 2005; Yogodzinski et al., 1994; Zack et al., 2002]. Variations on these models include melting of mantle wedge metasomatized by slab-derived fluid or melt [Eiler et al., 2007; Sajona et al., 1996] or the direct supply of felsic melt from eclogitic slab melting [Defant and Drummond, 1990; Martin, 1999; Martin et al., 2005]. Combined slab fluid and melt fluxes have also been proposed to explain geochemical variations along or across magmatic arcs [Eiler et al., 2005; Ishizuka et al., 2006]. Separate deep and shallow slab components have also been proposed [Kimura and Yoshida, 2006; Pearce and Peate, 1995; Pearce et al., 2005].

[3] Arc basalts characteristically have elevated contents of large-ion lithophile element (LILEs) and light rare earth element (LREEs) with depleted heavy REE (HREE) and high field strength ele- ments (HFSEs). There is a consensus that slab dehydration or melting combined with the interaction of this slab-derived flux with variously depleted mantle generates primary arc magmas with these characteristics. Arc primary magmas typically have radiogenic $\mathrm{Sr}$ and $\mathrm{Pb}$ isotopic composition, with less radiogenic $\mathrm{Nd}$ in lavas erupted from the volcanic front whereas rear-arc magmas are more similar to those derived from depleted upper mantle sources [Elliott et al., 1997; Ishizuka et al., 2003; Kelemen et al., 2003b; Kimura and Yoshida, 2006; Manning, 2004; Rapp and Watson, 1995; Stolper and Newman, 1994; Tatsumi and Eggins, 1995]. These features are difficult to explain without element fractionation occurring mainly in the downgoing slab via dehydration or melting. This slab component metasomatizes the overlying mantle as due to interaction with slab-derived fluid or melt [Hochstaedter et al., 2001; Kimura and Yoshida, 2006; Savov et al., 2005]. This metasomatism also leads to mantle melting, with resultant magmas rising toward the surface. Interaction of mantlederived melts with arc crust [Kersting et al., 1996; Kimura and Yoshida, 2006] causes a change in the primary arc magmas. These crustal interactions make it difficult to understand the composition of fractionated arc lavas, which makes it attractive to focus on primitive basalts.

[4] Two major but contrasting proposals exist to explain arc magma genesis. The first invokes the dehydration of oceanic plate slab whereas the other predicts direct melting of the slab. The fundamental control appears to be the pressure-temperature path of the subducting slab, which can be approximated by geodynamic modeling [Peacock and Wang, 1999]. In these models with an isoviscous mantle wedge, subduction of old and cold oceanic plate leads to low slab surface temperature. Sub- 
duction of young and hot oceanic crust results in higher slab surface temperatures [Stern et al., 2003]. One example of this contrasting behavior is shown by the arcs of NE and SW Japan [Peacock and Wang, 1999], where the Pacific Plate (>120 Ma old) and the Shikoku Basin (27-15 Ma old), respectively, are subducting beneath the same Eurasia plate [Kimura and Stern, 2009; Kimura et al., 2005; Kimura and Yoshida, 2006]. In this region, slab dehydration appears to dominate beneath the NE Japan arc and is responsible for the origin of primary arc basalts [Kimura and Yoshida, 2006; Moriguti et al., 2004; Shibata and Nakamura, 1997], whereas slab melting to generate high $\mathrm{Mg} \#$ andesite or adakitic dacite dominates in the SW Japan subduction zone [Kimura and Stern, 2009; Kimura et al., 2005; Shimoda and Nohda, 1995; Tatsumi and Hanyu, 2003].

[5] Similar contrasting behavior has been shown between arcs along the western and eastern Pacific rims. Arc magmatism due to slab-derived fluids are proposed for the western Pacific arcs, including the Kurile, NE Japan, and the Izu-Bonin-Mariana arcs [Ishikawa and Nakamura, 1994; Ishikawa and Tera, 1999; Ishizuka et al., 2003; Kimura and Yoshida, 2006; Moriguti et al., 2004; Pearce et al., 2005; Ryan et al., 1995; Straub and Layne, 2003], in addition to those in the Sunda-Banda arcs [Elburg et al., 2002, 2003; Foden and Green, 1992; Sendjaja et al., 2009; Turner and Foden, 2001]. Lavas from these cold subduction zones show abundances and isotopic compositions of extremely fluid mobile elements such as $\mathrm{B}, \mathrm{Li}$, or $\mathrm{U}$ that strongly suggest large-scale involvement of slab derived fluids to form high $\mathrm{Mg}$ \# primary mafic magmas [Ishikawa and Nakamura, 1994; Ishikawa and Tera, 1999; Moriguti et al., 2004; Ryan et al., 1995; Turner and Foden, 2001]. In contrast, slab melting better explains the origin of high $\mathrm{Mg}$ \# intermediate lavas in the eastern Pacific, including the Central America arc [Kelemen et al., 2003b; Straub et al., 2008] although the role of slab fluid is an important factor in high $\mathrm{Mg}$ \# basaltic andesite genesis in the Cascadia arc [Grove et al., 2006]. Within the context of these considerable variations in arc magma genesis models we examine fluid-fluxed high $\mathrm{Mg}$ \# basalt magma genesis using a geochemical mass balance approach. The mass balance model includes fluid dehydration of the downgoing altered oceanic crust and sediments (collectively called the slab), fluid transport into and through the mantle wedge, and fluid-fluxed melting in the mantle wedge. The basic modeling scheme is based on models devel- oped for cold subduction zones, such as NE Japan or Sunda arcs [Kimura and Stern, 2009; Kimura and Yoshida, 2006; Sendjaja et al., 2009]. Studies of fluid mobile isotopes from these basalts also have led to the widespread conclusion that slabderived fluids control the generation and composition of high $\mathrm{Mg}$ \# basalts in these arcs [Moriguti et al., 2004; Turner and Foden, 2001]. Our mass balance model is the Arc Basalt Simulator version 2 using an Excel ${ }^{\mathbb{R}}$ spread sheet and is developed particularly for high $\mathrm{Mg} \#$ basalt studies in such cold subduction zones. We concentrate our discussions on processes related to slab dehydration, fluid reaction and how this controls the mantle peridotite, and fluid-fluxed mantle melting. We have also examined models for coupled slab melting, mantle slab melt reaction, and mantle melting to explain the origin of high $\mathrm{Mg} \#$ andesite or adakite [Kimura and Stern, 2009; Tsuchiya et al., 2005, 2007] and are developing an Excel ${ }^{\mathrm{B}}$ based calculator for hot subduction zones. We are well aware that the relationship between slab fluid dominant and slab melt dominant magma genesis is also a matter of debate [Kimura and Stern, 2009]. While the current Arc Basalt Simulator does not provide perfect matches to all naturally occurring basalts, we consider its continued use and development critical in the evaluations of the mechanisms governing arc basalt genesis. In this paper, we describe the ABS2 modeling scheme and apply it to understand the origin of NE Japan arc basalts.

\subsection{Origin of Complexities in Cold Subduction Zone Basalt Chemistry}

[6] The complex behavior of elements in the slab and in the mantle wedge reflects the formation and decomposition of hydrous silicates such as mica, amphibole, lawsonite, chlorite, zoisite, as well as minor accessory minerals (e.g., rutile, zircon) along with essential minerals such as olivine, clinopyroxene, orthopyroxene, garnet, and spinel [Poli and Schmidt, 1995; Rapp and Watson, 1995; Schmidt and Poli, 1998; Sen and Dunn, 1994; Tollstrup and Gill, 2005]. The construction of a quantitative mass balance model of element behavior in subduction zones requires describing the mineral modes of altered oceanic crust (AOC; referring only to the igneous crust) and sediments (SED) as a result of prograde metamorphism in the downgoing slab and in the depleted wedge mantle (DMM) at appropriate $P$ - $T$ conditions.

[7] Experimentally determined element mobilities suggest that incompatible elements fractionate in 
fluids released during prograde metamorphism [Aizawa et al., 1999; Ayers et al., 1997; Ayers and Watson, 1993; Bebout et al., 1999; Brenan et al., 1995; Kogiso et al., 1997]. For example, low $\mathrm{Ba} / \mathrm{La}$ or high $\mathrm{Th} / \mathrm{Sm}$ in arc basalts are used to identify involvement of sediment melt [Elliott et al., 1997; Plank and Langmuir, 1993], whereas high $\mathrm{Ba} / \mathrm{Th}$ or $\mathrm{Pb} / \mathrm{Ce}$ suggest contributions from a slab fluid [Hawkesworth et al., 1993; Pearce et al., 2005; Stolper and Newman, 1994; Turner et al., 1997]. Such conclusions are supported by the behavior of strongly fluid mobile elements such as $\mathrm{As}, \mathrm{Sb}, \mathrm{B}, \mathrm{Cl}, \mathrm{F}, \mathrm{Li}, \mathrm{Rb}$, and $\mathrm{Cs}$ in arc basalts [Bebout et al., 1999; Marschall et al., 2007; Straub and Layne, 2003]. The elemental abundances and ratios are not always directly related to isotopic variations, such as $\mathrm{Sr}$ and $\mathrm{Pb}$ isotopes, suggesting that complex chemical interactions occur in the subduction zone environment. Element partitioning between minerals and fluid or melt $\left(D_{\text {minerallfluid, }}\right.$ $\left.D_{\text {melt/mineral }}\right)$ has therefore been an important research subject for understanding subduction zone magmatism [Aizawa et al., 1999; Ayers et al., 1997; Brenan et al., 1995; Green and Adam, 2003; Green et al., 2000; Johnson and Plank, 1999; Kessel et al., 2005a; Marschall et al., 2006; Stalder et al., 1998; Zack et al., 2002]. Element mobility depends strongly on $P-T$ conditions. For example, "fluidimmobile" elements, such as $\mathrm{Th}$ or $\mathrm{Nb}$, become quite mobile at high temperature [Kessel et al., 2005a; Stalder et al., 1998]. This temperature dependence has been predicted for $D_{\text {melt }}$ mineral by lattice strain models [Blundy and Wood, 1994; van Westrenen and Draper, 2007], and should also be true for $D_{\text {minerallfluid }}$ [Kessel et al., 2005a]. A systematic investigation of these influences still needs to be carried out.

[8] Further complexity is reported from studies of fluid evolution in high $P-T$ metamorphic rocks. These studies show that local chemical conditions or chromatographic chemical reactions dictate how and where elements are mobilized or precipitated [Breeding et al., 2004; Gao et al., 2007; King et al., 2003, 2006, 2007] and how they are likely to behave in the mantle wedge [Ionov and Hofmann, 1995; Navon et al., 1996; Verniéres et al., 1997]. The significance of this local disequilibrium for element mass balance in metamorphic rocks [Bebout et al., 1999; Manning, 2004; Spandler et al., 2004] or for the arc-scale homogeneity of basalt magmas [Gill, 1981] is not always clear. These global phenomena appear to control element mobility in subduction zones [Pearce and Peate, 1995].

\subsection{Arc Mass Balance Model Development}

[9] Progress toward quantitative subduction zone mass balance has been made mainly using forward modeling to explain arc basalt compositions [Ayers, 1998; Kelemen et al., 2003b; Kimura and Yoshida, 2006; Marschall et al., 2007; McCulloch and Gamble, 1991; Navon et al., 1996; Navon and Stolper, 1987; Stolper and Newman, 1994; Straub and Layne, 2003; Tatsumi and Hanyu, 2003]. Insights from recent progress include the following:

[10] 1. Experimental results describe element partitioning between slab materials and fluid/melt [Aizawa et al., 1999; Johnson and Plank, 1999; Kessel et al., 2005a; Kogiso et al., 1997; Sen and Dunn, 1994], between peridotite and slab-derived fluid/melt [Ayers, 1998; Rapp and Watson, 1995], and the element partitioning between peridotite and basaltic melt [Green, 1994; Green et al., 2000; McDade et al., 2003a, 2003b; Salters et al., 2002]. These enable us to calculate multiple element behavior during subduction zone magma genesis [Kimura and Yoshida, 2006].

[11] 2. Development of thermodynamic models for prograde metamorphism [Connolly and Kerrick, 1987; Connolly and Petrini, 2002] and mantle melting [Ghiorso et al., 2002; Smith and Asimow, 2005] provides mineralogic modes as a function of $P$ and $T$.

[12] 3. Recent progress also provides insight on realistic subduction zone $P$ - $T$ structures from geodynamic models [Peacock et al., 2005; van Keken, 2003] and geological constraints [Kelemen et al., 2003a].

[13] 4. Additional support comes from improved understanding of $P$ - $T$-dependent element partitioning between minerals and melt/fluid, using thermodynamic models [Blundy and Wood, 1994; van Westrenen and Draper, 2007] and experimental observations [Kessel et al., 2005a; Stalder et al., 1998].

[14] 5. Further support comes from the characteristics of hydrous mantle melting [Asimow et al., 2004; Hirose and Kawamoto, 1995; Katz et al., 2003]. Observations about the behavior of elements in natural systems include those in altered oceanic crust, marine sediment, and mantle peridotite source rocks for subduction zone magmatism [Hauff et al., 2003; Kelley et al., 2003; Plank and Langmuir, 1998; Savov et al., 2005]; and those in metamorphic rocks during prograde reactions [Bebout et al., 1999; Kimura and Yoshida, 2006; 
Marschall et al., 2006; Spandler et al., 2004; Wunder et al., 2005, 2006].

\subsection{Arc Magmatism Modeling: An Approach}

[15] Using these recent developments we propose a model to explain the generation of high $\mathrm{Mg} \#$ arc basalt via slab dehydration and subsequent fluidfluxed mantle melting. High $\mathrm{Mg}$ \# basalt occurs in most magmatic arcs, particularly in cold subduction zones [Ishizuka et al., 2006; Kelemen et al., 2003b; Stolper and Newman, 1994; Tatsumi and Eggins, 1995; Wilson, 1989]. Because of their low $\mathrm{SiO}_{2}$ contents and high $\mathrm{MgO}, \mathrm{Ni}$, and $\mathrm{Cr}$ contents, high $\mathrm{Mg}$ \# basalts are believed to be melts of mantle wedge peridotite [Gill, 1981; Kelemen et al., 2003b; Stolper and Newman, 1994; Tatsumi and Eggins, 1995; Wilson, 1989]. High magmatic water contents in proportion to fluid-mobile LILEs indicate that slab-derived fluids were added to the mantle source. This should generate high-degree partial melts, leading to HFSE and HREE depletions [Kelley et al., 2006; Kimura and Stern, 2009; Kimura and Yoshida, 2006; Stolper and Newman, 1994; Straub and Layne, 2003].

[16] Here we describe a forward modeling scheme based on quantitative geochemical mass balance to explain the trace element and isotopic composition of high $\mathrm{Mg} \#$ arc basalts. This is an extension of an earlier model described by Kimura and Yoshida [2006] and later proposed as Arc Basalt Simulator (ABS) version 1 [Kimura and Stern, 2009; Sendjaja et al., 2009]. The ABS version 1 model [Kimura and Stern, 2009; Sendjaja et al., 2009] consists of three modules: (1) temperature-pressure-dependent element partitioning between the slab and an evolved fluid [Kessel et al., 2005a], (2) fluidmantle reaction based on zone refining [Ayers, 1998], and (3) open system dynamic melting of fluxed mantle peridotite [Ozawa, 2001; Ozawa and Shimizu, 1995; Zou, 1998]. ABS version 2 (hereafter, ABS2) has three similar modules (Figure 1). In addition, ABS2 includes a slab dehydration simulator (SDS) which calculates slab-derived fluids resulting from prograde metamorphism [Hacker, 2008; Marschall et al., 2007] using Perple_X version 7 [Connolly and Kerrick, 1987; Connolly and Petrini, 2002]. The slab mineralogy and the amount of $\mathrm{H}_{2} \mathrm{O}$ generated by dehydration are calculated along a slab P-T path, which is provided for specific subduction zones by high-resolution finite element models [van Keken, 2003]. Temperature-dependent $D_{\text {mineralffluid }}$ values [Kessel et al., 2005a; Stalder et al., 1998] are incorporated in the slab dehydration model whenever possible; this is especially important because the temperature variations expected for prograde metamorphism associated with slab dehydration are greater than that for mantle melting. Available $D_{\text {minerallfluid }}$ values for hydrous minerals [Feineman et al., 2007; Green and Adam, 2003] are also included. The compositions of the slab and the dehydrated fluid are calculated using the SDS model (indicated by 1 in Figure 1).

[17] Zone-refining reactions are used within (1) the hydrous mineral-bearing low- $T$ metasomatized mantle sole, directly above the slab (indicated by 2.1 in Figure 1; e.g., chlorite-harzburgite [Garrido et al., 2005]) and (2) the hydrous mineral-free high- $T$ mantle wedge (indicated by 2.2 in Figure 1 [Ayers et al., 1997]). A $P-T-X_{2} \mathrm{O}$ constrained open system melting is formulated using the $P-T$ $\mathrm{XH}_{2} \mathrm{O}-\mathrm{F}$ (where $\mathrm{XH}_{2} \mathrm{O}$ is mass fraction of fluid added to peridotite, and $F$ is the degree of partial melting) relation of Katz et al. [2003] and the open system melting model of Ozawa and Shimizu [1995] and Zou [1998]. This melting calculation includes mantle mineralogy calculated by pMELTS with the Adiabat_1ph version 7 front end [Asimow et al., 2004; Ghiorso et al., 2002] at a given $P-F$ condition (indicated by 3 in Figure 1).

\section{Model Description}

[18] ABS2 uses three separate modules (Figure 2): the first quantifies slab dehydration (SDS), the second quantifies zone refining (ZR), and the third quantifies fluid-fluxed mantle melting (OSM).

\subsection{Source Materials}

[19] The source materials that feed subduction zone magmatism include sediments (SED) and altered oceanic crust (AOC) in the subducting slab and the mantle wedge peridotite (PERID) (source box in Figure 2). Subducted serpentinized mantle and metagabbro may also contribute fluid, but these are not considered. The compositions of these three components are denoted $X_{S E D}, X_{A O C}$, and $X_{P E R I D}$. SED components can be further described as chert $\left(\mathrm{CH} ; X_{C H}\right)$, pelagic clay (CLAY; $\left.X_{C L A Y}\right)$, or terrigenous sediment (TERR: $X_{\text {TERR }}$ ) [e.g., Plank and Langmuir, 1998]. Carbonate sediments can also be subducted but this is not modeled because $D_{\text {mineralffluid }}$ values of carbonate minerals are poorly known for the elements of interest in this paper. The user can define the slab AOC composition or 


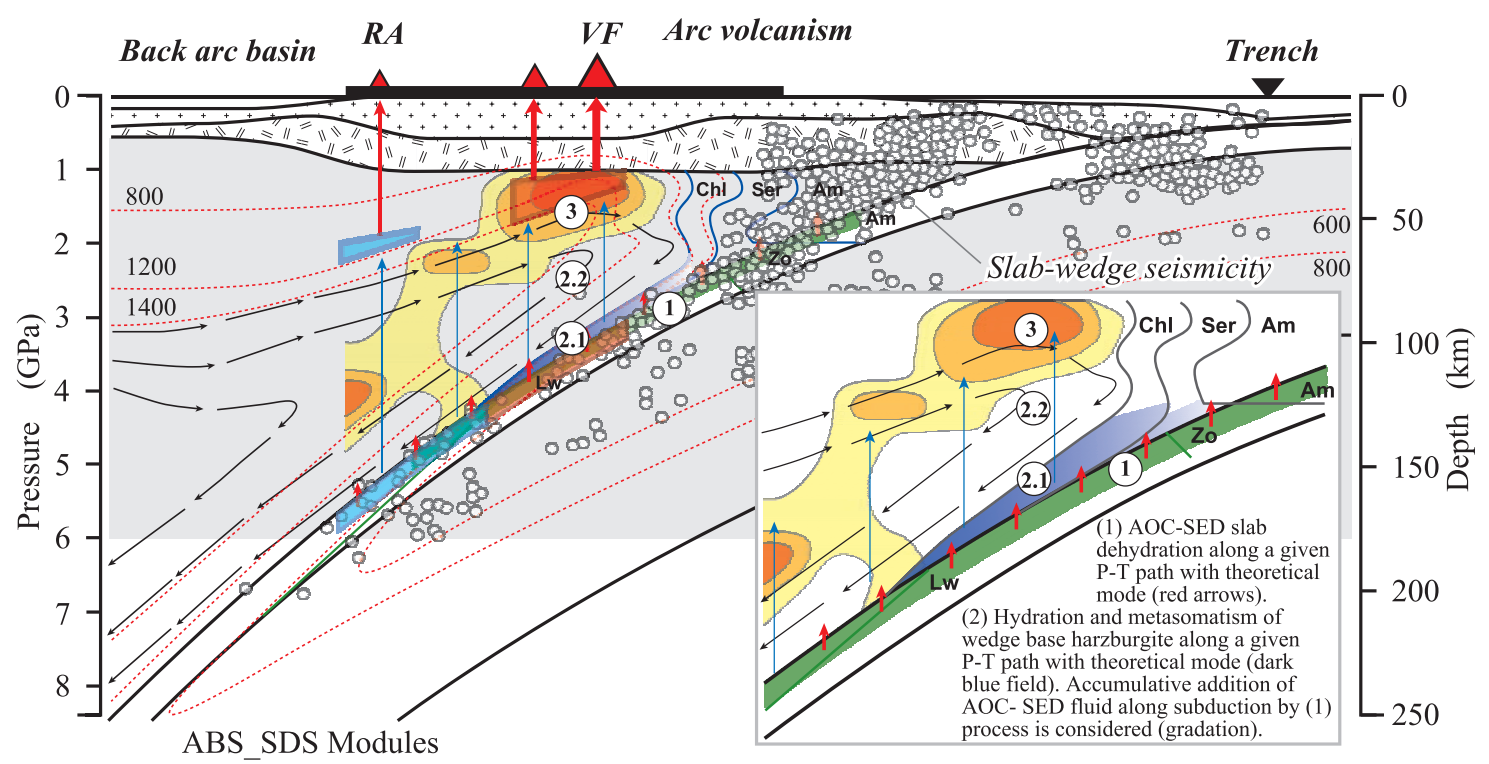

1. Dehydration of subducted sediment and altered oceanic crust with theoretical slab mineralogy

2.1 Hydration of mantle wedge sole with theoretical mineralogy and zone refining reaction

2.2 Fluid transport and interaction with mantle by zone refining reaction

3. Melting in the mantle wedge with open-system dynamic melting

Figure 1. Summary of the four ABS2 modules, which simulate geochemical reactions during dehydration of subducted sediment and altered oceanic crust (indicated by 1), hydration of mantle wedge sole and reaction with slabderived fluid (indicated by 2.1), fluid flow in the mantle and fluid-mantle reaction (indicated by 2.2), and fluid-fluxed melting of the mantle wedge (indicated by 3 ). This section is based on seismic tomography beneath NE Japan [Nakajima et al., 2005]; Moho depth, crustal structure, mantle wedge isotherms (red dotted thin line with numbers) $\left({ }^{\circ} \mathrm{C}\right)$, and flow lines (thin black arrows) are modified after Kelemen et al. [2003a]. Pale gray shading shows pressure interval modeled by ABS2. Hydrous mineral stability fields [Poli and Schmidt, 1995] are fitted to P-T conditions in the cross section. Chl, chlorite; Ser, serpentine; Am, amphibole; Zo, zoisite; Lw, lawsonite; RA, rear arc volcano; VF, volcanic front volcano. Yellow to orange shades in the mantle wedge are variations in $V s$ and are inferred to correspond to elevated melt or fluid concentrations. Gray open dots indicate seismicity; red triangles indicate volcanos; green area indicates slab dehydration region; blue wedge in the mantle wedge sole indicates metasomatized peridotite; red and blue shaded areas in slab indicate slab fluid source regions for VF and RA volcanics, respectively; red and blue areas in mantle wedge indicate mantle melting regions used by ABS2 model; small red arrows indicate slab dehydration; thin blue arrows indicate fluid flow in mantle wedge; and thick red arrows indicate basalt magma transfer.

use N (normal)-MORB composition [e.g., Albarède, 2005; Hauff et al., 2003; Kelley et al., 2003].

[20] The PERID composition appropriate for a specific arc is difficult to constrain without mantle xenoliths [e.g., Kimura and Yoshida, 2006]. Two end-member options we consider are depleted MORB mantle composition (DMM [Salters and Stracke, 2004; Workman and Hart, 2005]) and the primitive mantle composition (PM [Sun and McDonough, 1989]). The mantle wedge beneath arcs is believed to be more depleted than any other mantle source [Davidson, 1996; Kimura and Yoshida, 2006; Stern, 2002]. We thus approximate variously depleted mantle compositions by extracting MORB basalt melt from DMM and PM sources using a fractional melting model. The melting mineralogy is estimated using pMELTS [Ghiorso et al., 2002; P. M. Smith and P. D. Asimow, 2005b, Instructions for Adiabat_1ph program and Run Adiabat.pl script; Text driven interfaces for MELTS, pMELTS and pHMELTS, available at http://www.gps.caltech.edu/ asimow/adiabat/] using the DMM major element compositions in the spinel peridotite stability field [Workman and Hart, 2005] at $1 \mathrm{GPa}$. The basalt melt composition extracted from the source at a given $F$ is calculated using published partition coefficients [Green, 1994; Green et al., 2000; McDade et al., 2003a, 2003b] (see the "Per_Dep" worksheet in the ABS2 Excel ${ }^{\circledR}$ spreadsheet in Software S1). ${ }^{1}$ Extraction of MORB basalt melt up to $30 \mathrm{wt} \%$ of mantle mass is allowed, and is computed in $0.1 \%$ MORB extraction steps. The same melting mode is applied to the PM composi-

${ }^{1}$ Auxiliary materials are available in the HTML. doi:10.1029/ 2008GC002217. 


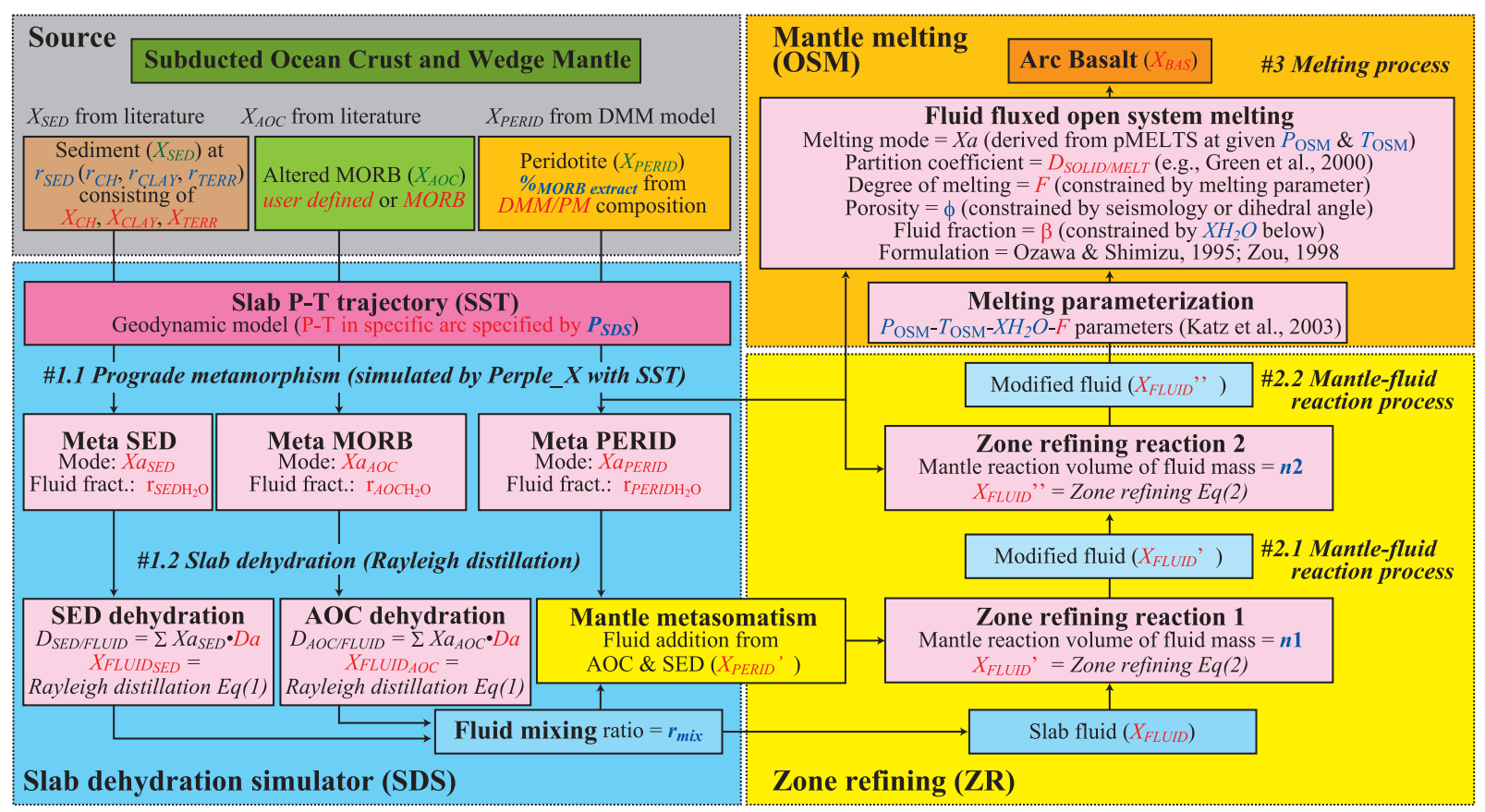

Figure 2. Flow diagram for ABS2, with slab dehydration simulator (SDS) module as front end. Flow progresses from top left to bottom then top right. Blue italics are user inputs, and red italics are calculated by ABS2. Pale brown, pale green, and pale orange boxes are inputs for sediment, AOC, and peridotite compositions. SED consists of chert $(\mathrm{CH})$, pelagic clay (CLAY), and terrigeneous sediment (TERR) mixed in the proportion $r_{S E D}$. Dark pink box indicates $P-T$ trajectory of the slab-wedge interface (SST, must be input from a geodynamic model). Pale pink boxes indicate fluid/melt compositions calculated at each stage using parameters shown in red italics in the box. $X a$, modes; $r_{H 2 O}$, mass fraction of dehydrated fluid. Small yellow box indicates calculation of metasomatism of mantle wedge sole $X_{\text {PERID }} . D a$, partition coefficients of minerals. $\Sigma$ indicates sum of $X a \times D a$ (fluid-rock partition coefficients) including $n=1$ to $n=\mathrm{x}$, where $\mathrm{x}$ is the number of minerals (same as bulk $D$ for partial melting). Pale blue indicates slab fluid composition $\left(X_{F L U I D}\right)$ calculated at each step. Mixing ratio $\left(r_{\text {mix }}\right)$ between $X f l u i d_{S E D}$ and $X f l u i d_{A O C}$ in the first blue box is entered by user. Zone refining (large yellow box) alters $X_{F L U I D}$ composition by reaction with metasomatized wedge sole peridotite (zone-refining reaction 1) then wedge core peridotite (zone-refining reaction 2) to generate modified fluid $\left(X_{F L U I D}^{\prime}\right.$ and $\left.X^{\prime \prime}{ }_{F L U I D}\right)$. Fluid flux melting (orange box) assumes open system melting using $\mathrm{T}-\mathrm{P}-\mathrm{XH}_{2} \mathrm{O}-\mathrm{F}$ parameterization. $\mathrm{XH}_{2} \mathrm{O}, \mathrm{H}_{2} \mathrm{O}$ added to mantle source; $\beta$, mass fraction of fluid in total melt mass in an open system melting; $\phi$, residual melt mass fraction of melting system; $F$, degree of melting; $D_{M E L T}$, bulk partition coefficient of mantle; $P_{O S M}$, pressure of open system melting; $T_{O S M}$, temperature of open system melting. Dark orange indicates calculated basalt melt composition $X_{B A S}$.

tion. PM source mantle wedge may be more appropriate as a starting mantle compositions where the subarc mantle experienced fertile mantle upwelling or alkali basalt melt addition from a deep fertile mantle source (e.g., SW Japan [Kimura and Stern, 2009] and Central America [Carr et al., 2007]), or where enriched lithospheric mantle is involved. As discussed below, the $\%$ MORB extraction factor is used as a parameter for fitting the model basalt and natural basalt compositions.

\subsection{Slab Dehydration Simulator}

\subsubsection{SDS Prograde Metamorphism}

[21] The first calculation module, the slab dehydration simulator (SDS), simulates slab-derived fluid compositions using the slab source compositions given above. The module uses Perple X version 7 [Connolly and Kerrick, 1987; Connolly and Petrini, 2002] to calculate the prograde metamorphism of SED (CH, CLAY, TERR), AOC, and mantle PERID component parameters using the source compositions and activity models reported by Hacker [2008]. The major element source compositions $\left(X_{C H}, X_{C L A Y}, X_{T E R R}, X_{A O C}\right.$, and $\left.X_{\text {PERID }}\right)$ allow generation of mineralogical modes and bound $\mathrm{H}_{2} \mathrm{O}$ over the $P-T$ range $0.1-6 \mathrm{GPa}$ (in $0.1 \mathrm{GPa}$ steps), and $100-1200^{\circ} \mathrm{C}\left(100^{\circ} \mathrm{C}\right.$ steps $)$ (see SDS module in Figure 2). $\mathrm{H}_{2} \mathrm{O}$ saturation is assumed at beginning of subduction at the lowest $P-T\left(0.5 \mathrm{GPa}, 100^{\circ} \mathrm{C}\right)$ condition. Prograde metamorphism causes continuous dehydration with increasing P-T [Hacker, 2008], therefore, amount of 
$\mathrm{H}_{2} \mathrm{O}$ in SED, AOC, and PERID components are limited by bound $\mathrm{H}_{2} \mathrm{O}$ in the lattice of hydrous metamorphic minerals. Amount of pore fluid is assumed to be absent in slab components at the pressures of interest here. Therefore, our model assumes solidus of SED, AOC, and PERID to be dehydration solidus rather than water-saturated solidus. This assumption is important in defining slab conditions whether it is melted or not. At this time we do not consider slab melting in the cold NE Japan subduction zone. Representative phase diagrams and bound $\mathrm{H}_{2} \mathrm{O}$ isopleths for the TERR, AOC, and PERID (DMM) components are shown in Figures $3 \mathrm{a}, 3 \mathrm{~d}$, and $3 \mathrm{~g}$.

[22] On the basis of petrogenetic grids calculated by Perple $X$, it is possible to model the changes in mineralogical mode $\left(X a_{S E D}, X a_{A O C}, X a_{P E R I D}\right)$ and bound $\mathrm{H}_{2} \mathrm{O}$ in the slab during prograde metamorphism along a designated slab surface $P-T$ trajectory (SST in Figures 2 and 3). The slab $P$ - $T$ paths were calculated using a finite element model designed to reveal subduction zone thermal structure [van Keken et al., 2002], using temperature-dependent olivine rheology except for one isoviscous olivine rheology model for the Izu arc [van Keken, 2003], and discretized for the purpose of ABS2 into $0.1 \mathrm{GPa}$ and $100^{\circ} \mathrm{C}$ steps (see Slab_Mode worksheet in Software S1). Figures 3a, 3d, and $3 \mathrm{~g}$ show an example of SST calculated for the subduction zone beneath the Tohoku (NE) Japan arc, which is similar to the model published by van Keken [2003]. Figures 3b, 3e, and $3 \mathrm{~h}$ indicate the modal abundances of major minerals along the SST. Figures $3 \mathrm{c}, 3 \mathrm{f}$, and $3 \mathrm{i}$ indicate the bound $\mathrm{H}_{2} \mathrm{O}$ of TERR, AOC, and DMM along the SST (see also Slab_Mode worksheet in Software S1). The biggest changes in bound $\mathrm{H}_{2} \mathrm{O}$ occur around $3 \mathrm{GPa}$ ( $\sim 100 \mathrm{~km} \mathrm{depth),} \mathrm{corresponding} \mathrm{to} \mathrm{the} \mathrm{consump-}$ tion of hydrous silicates such as amphibole, lawsonite, chlorite, and serpentine. Phengite survives in TERR and AOC to $6 \mathrm{GPa}$. The bound $\mathrm{H}_{2} \mathrm{O}$ content at 3-6 GPa is thus proportional to modal phengite in the slab; phengite abundance in turn depends on the $\mathrm{K}_{2} \mathrm{O}$ content of the subducted slab, especially SED [Hacker, 2008]. The dehydrated mass fraction of $\mathrm{H}_{2} \mathrm{O}$ from SED, AOC, and PERID components $\left(r_{S E D H 2 O}, r_{A O C H 2 O}, r_{P E R I D H 2 O}\right)$ are obtained by stepwise differentiation of the bound $\mathrm{H}_{2} \mathrm{O}$ (see SDS module in Figure 2). Note that the activity model for amphibole is $\mathrm{K}$ free, maximizing the stability of phengite [Hacker, 2008].

[23] The Perple_X calculation does not include melt generation. The $\mathrm{H}_{2} \mathrm{O}$-saturated and dehydra- tion solidi for TERR, MORB [Schmidt et al., 2004], and PERID [Grove et al., 2006] are shown in the same plots (Figures 3a, 3d, and 3g). For the Tohoku SST, slab melting may or may not occur, depending on $\mathrm{H}_{2} \mathrm{O}$ saturation in the slab (Figure 3). Melting of the slab likely occurs at dehydration solidus conditions rather than at $\mathrm{H}_{2} \mathrm{O}$-saturated solidus determined experimentally by $\mathrm{H}_{2} \mathrm{O}$ oversaturated conditions (see two different solidus curves in Figure 3).

\subsubsection{SDS Element Partitioning}

[24] Given the mineralogical mode and dehydration of the subducted slab, it is possible to calculate the slab-derived fluid composition, using an approach similar to that of Marschall et al. [2007]. The key parameter is $D_{\text {mineralffluid }}$ of the prograde metamorphic minerals (for minerals used, see slab mineralogy in Software S1 Control_Panel, also see Figure 6).

[25] The temperature-dependent $D_{\text {mineral fluid }}$ values are available for garnet and clinopyroxene [Kessel et al., 2005a]. Kessel et al. [2005a] used a K-free MORB composition for experimental runs and determined fluid-MORB partition coefficients of trace elements at 4 and $6 \mathrm{GPa}$ between 700 and $1400^{\circ} \mathrm{C}$. Their $P-T$ conditions include the second critical end point for fluid and melt [Kessel et al., 2005a, 2005b]. Element behavior may be different in this particular $P-T$ range; however, their experiments were done with insufficient $\mathrm{H}_{2} \mathrm{O}$ contents to achieve second critical end point conditions. Therefore, the determined partition coefficients between fluids and minerals are applicable for solid-fluid at 4-5 GPa, and solid-fluid at $6 \mathrm{GPa}$ with coexisting melt. Their results also agree with earlier experiments done at similar or lower pressures [Brenan et al., 1995; Stalder et al., 1998].

[26] Partition coefficients between garnet and fluid depend strongly on temperature, showing a quasi$\log$ linear $D-T$ relationship either with $T={ }^{\circ} \mathrm{C}$ (Figure 4) or $T=1000 /{ }^{\circ} \mathrm{K}$ (not shown). Slight pressure dependence is seen, indicating greater $D_{\text {fluid/garnet }}$ in Th and LREE at high pressure (Figure 4). In contrast, LILEs such as $\mathrm{Ba}$ are insensitive to pressure because of their high incompatibility in anhydrous solids under all conditions [Pearce and Peate, 1995]. HFSEs such as $\mathrm{Nb}$ are buffered by residual rutile due to an extremely high partition coefficient [Green, 1995], and show little if any pressure dependence [Kessel et al., 2005a] (Figure 4). Such relationships encourage the formulation of $T-D_{\text {mineralfluid }}$ rela- 

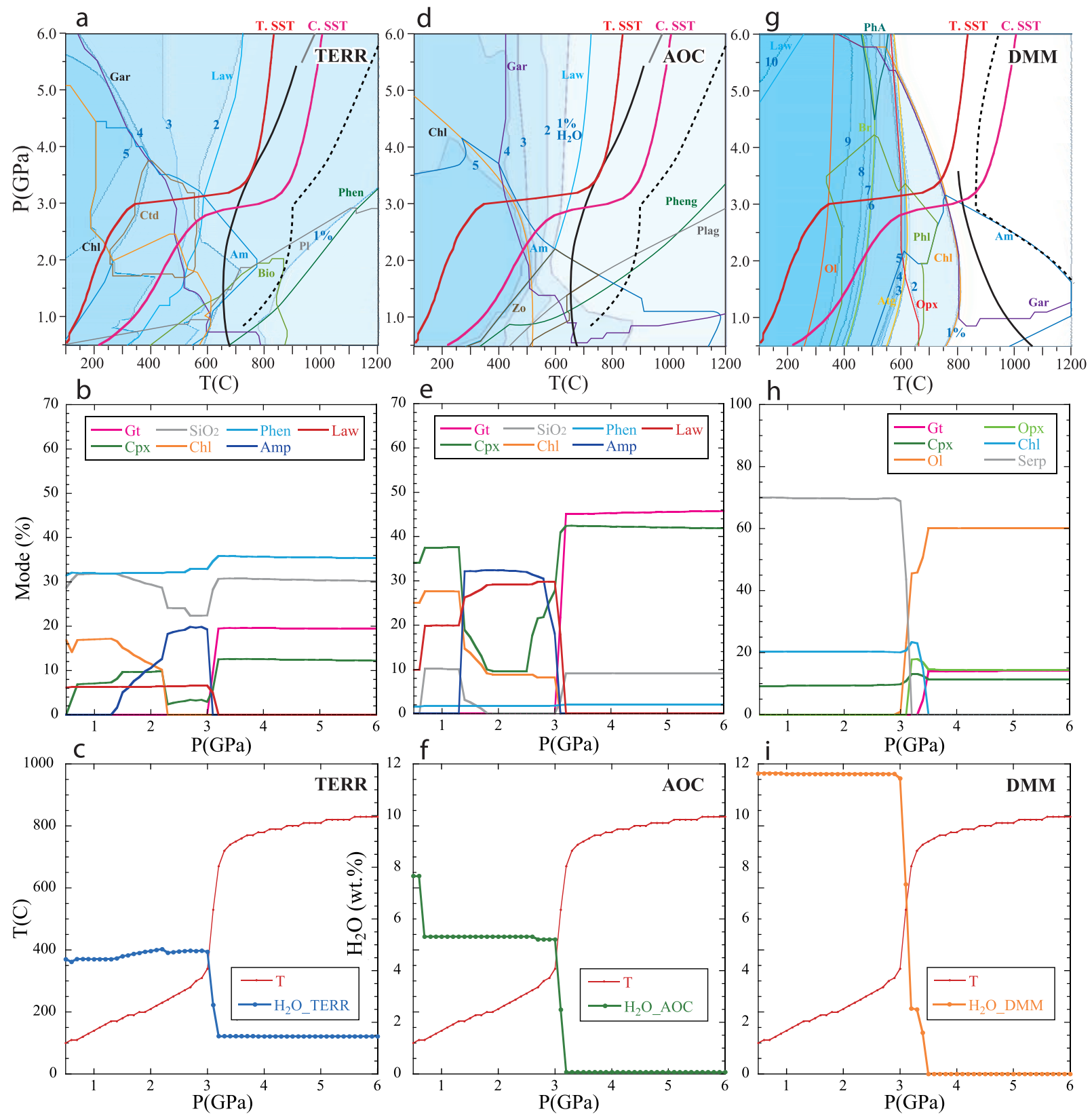

Figure 3. Metamorphic equilibria and fluid evolution for subducted slabs, using the Tohoku subduction zone as an example. The behavior of $(\mathrm{a}-\mathrm{c})$ subducted terrigeneous sediment $(\mathrm{TERR}),(\mathrm{d}-\mathrm{f})$ altered oceanic crust (AOC), and ( $\mathrm{g}-\mathrm{i}$ ) depleted MORB mantle (DMM). Figures 3a, 3d, and 3g show phase stability fields (outlined by various colored lines) and wt $\%$ bound $\mathrm{H}_{2} \mathrm{O}$ (blue fields). Red thick line (T. SST) and pink thick line (C. SST) show P-T paths for Tohoku and Cascades subduction slab interfaces, respectively, as examples of cold and hot subduction zones. Black solid lines indicate $\mathrm{H}_{2} \mathrm{O}$-saturated solidi, and black dotted lines indicate dehydration melting solidi [Grove et al., 2006; Schmidt et al., 2004]. Figures 3b, 3e, and 3h show phase proportions as a function of P. Gt, garnet; $\mathrm{SiO}_{2}$, silica minerals (quartz, coesite, and stishovite); Phen, phengite; Law, lawsonite; Cpx, clinopyroxene; Chl, chlorite; Amp, amphibole; Serp, serpentinite minerals such as antigorite. Figures $3 \mathrm{c}, 3 \mathrm{f}$, and $3 \mathrm{i}$ show wt $\%$ bound $\mathrm{H}_{2} \mathrm{O}$ as a function of pressure for subducted sediment and altered oceanic crust and for DMM just above slab interface; temperature along the Tohoku slab interface is also shown in red. 

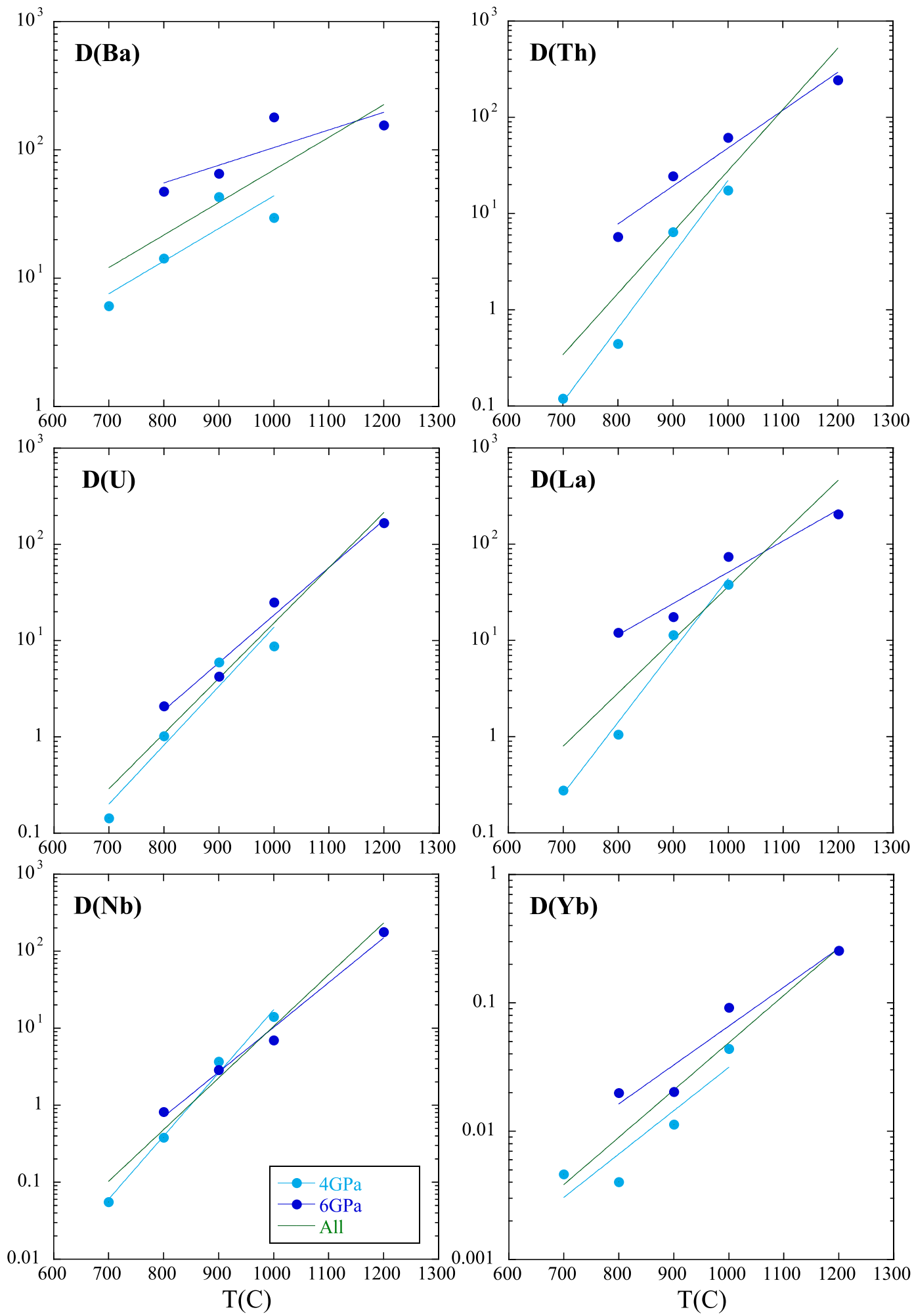

Figure 4. Examples of temperature- and pressure-dependent partition coefficients between garnet in K-free MORB and fluids $\left(D_{\text {fluid/garnet }}\right)$. Data from Kessel et al. [2005a]. Clear temperature-dependent increases in $D_{\text {fluid/garnet }}$ are observed. The relationship is clearer in $D$ versus $1000 / \mathrm{K}$, but use of $T\left({ }^{\circ} \mathrm{C}\right)$ is adequate. Note that Figure 4 treats fluid/ garnet rather than garnet/fluid as in other parts of this paper. 
tionships as $D_{\text {minerallfluid }}=\mathrm{a} \times \exp ^{\mathrm{b} T}$, where "a" and " $\mathrm{b}$ " are constants for garnet and clinopyroxene from Kessel et al. [2005a] (see SDS worksheet in Software S1). Partition coefficients with weak pressure dependence are treated without consideration of pressure dependence; this treatment gives reasonable estimates of $D$ s over a large range in $P$ (see Figure 4).

[27] The SDS module uses a temperature range of 100 to $1200^{\circ} \mathrm{C}$ and therefore an extrapolation of $D-T$ relationship to low temperatures $\left(<700^{\circ} \mathrm{C}\right)$ is necessary. An exponential $T$ dependence of $D$ has been reported for $D_{\text {mineral/melt }}$ using the lattice strain model [Blundy and Wood, 1994; van Westrenen and Draper, 2007]. The dependence is derived for $D_{0}$, the partition coefficient of an element with ideal ionic radius for the mineral lattice site. $D$ values for other elements follow the same $T$ dependence. Theoretical calculations predict that the $T$-dependent slope of $D_{\text {garnet/melt }}$ is almost parallel to the $D_{\text {garnetfluid }}$ determined by Kessel et al. [2005a] (not shown) although $D_{\text {garnet/melt }}$ is several orders of magnitude smaller than $D_{\text {garnetffluid }}$. $D_{\text {mineralffluid }}$ greater than unity does not greatly affect element fractionation in fluids during dehydration. We apply this simple extrapolation of the $T$ dependence for $D_{\text {minerallfluid. }}$ Kessel et al. [2005a] did not determine partition coefficients for $\mathrm{K}, \mathrm{Pr}, \mathrm{Tb}$, and $\mathrm{Ho}$. Average of $D_{\text {mineralffluid }}$ for neighboring REEs are applied to $\mathrm{Pr}$, Tb, and Ho. $D_{\text {mineralffluid }}(\mathrm{K})$ is assumed to be the same as $D_{\text {minerallfluid }}(\mathrm{Rb})$ because of the similar chemical behavior of these elements [Pearce and Peate, 1995] for clinopyroxene, garnet, and rutile.

[28] At low pressure and temperature the element behavior in oceanic basalt is affected by many minerals. Even after eclogitization, $\mathrm{K}$ is controlled by phengite, which possesses high $D_{\text {mineral/fluid }}$ only for $\mathrm{K}$ and $\mathrm{Rb}$ (and $\mathrm{B}, \mathrm{Ba}, \mathrm{Nb}, \mathrm{Ta}$, and $\mathrm{Pb}$ to a lesser extent) [Green and Adam, 2003; Green et al., 2000]. Sheet silicates and other hydrous minerals such as lawsonite, chloritoid, and zoisite are stable in subducted SED or AOC [Poli and $S c h m i d t, 1995]$. These can retain considerable amounts of trace elements, such as REE in lawsonite and chloritoid and $\mathrm{Sr}$ in zoisite [Feineman et al., 2007; Green and Adam, 2003]. We applied $D_{\text {mineralffuid }}$ for lawsonite, chloritoid, phengite [Green and Adam, 2003], and zoisite [Feineman et al., 2007] from experiments, and for lawsonite [Usui et al., 2007] from field studies. The $D_{\text {mineralffluid }}$ for olivine and rutile were taken from Ayers et al. [1997] and Ayers and Watson [1993]. These partition coefficients were determined at a range of relatively high $P-T\left(650-700^{\circ} \mathrm{C}, 2 \mathrm{GPa}\right.$ [Green and Adam, 2003], $750-900^{\circ} \mathrm{C}, 2 \mathrm{GPa}$ [Feineman et al., 2007], and $900-1100^{\circ} \mathrm{C}, 2-3 \mathrm{GPa}$ [Ayers et al., 1997]), but we use them without extrapolation. We consider it crucial to better determine the $T$ dependence of $D_{\text {minerallfluid }}$ in these minerals. Another way to constrain element partitioning within subduction zones is to extrapolate $D_{\text {minerallmineral }}$ determined for metamorphic rocks [Marschall et al., 2007]. We used this method for $D_{o p x / c p x}$ [Spandler et al., 2004], Damphibole/cpx [Ionov and Hofmann, 1995], and $D_{\text {chloritelopx }}$ [Garrido et al., 2005]. Ds for amphibole, orthopyroxene, and chlorite were inferred from $T$-dependent $D$ s in clinopyroxene or garnet.

[29] The $D$ values for silica minerals (quartz, coesite, stishovite) or aluminous minerals (such as sapphirine) were treated as $D_{\text {minerallfluid }}=0$ (J.-I. Kimura, unpublished laser ablation data, 2005). There are no data for talc and antigorite available for multiple element examination used in this study, which were also treated as $D_{\text {mineralffluid }}=0$.

[30] Overall element abundances during slab dehydration based on SDS calculations decrease the slab source compositions for fluid mobile elements such as $\mathrm{Rb}, \mathrm{K}, \mathrm{Ba}$, and $\mathrm{Pb}$ by up to $15 \%$ of the initial mass, whereas other elements such as REE and HFSE change little and source depletion is typically less than few percent (see graphics in Software S1 SDS module). The overall behavior that we calculate because of slab dehydration is consistent with observations of natural metamorphic rocks up to eclogite facies [Bebout et al., 1999; Spandler et al., 2004].

\subsubsection{SDS Slab Dehydration}

[31] To calculate the slab fluid composition, the bulk metasediment composition is defined by $\left(r_{S E D}\right.$ consisting of $\left.r_{C H}, r_{C L A Y}, r_{T E R R}\right)$ between $\mathrm{CH}$, CLAY, and TERR where $r_{C H}+r_{C L A Y}+r_{T E R R}=1$ giving source SED composition $X_{S E D}=r_{C H} \times$ $X_{C H}+r_{C L A Y} \times X_{C L A Y}+r_{T E R R} \times X_{T E R R}$. Isotopic compositions of the sediments are also calculated by this equation with consideration of element abundances. The bulk metasediment (SED) mineral mode $\left(X a_{S E D}\right)$ is also calculated by mixing the mineralogical modes of $X a_{C H}, X a_{C L A Y}$, and $X a_{T E R R}$ by by $X a_{S E D}=r_{C H} \times X a_{C H}+r_{C L A Y} \times X a_{C L A Y}+r_{T E R R} \times$ $X a_{\text {TERR }}$. The mass fraction of dehydrated fluid of SED is calculated in the same way: $r_{S E D H 2 O}=$ $r_{C H} \times r_{C H H 2 O}+r_{C L A Y} \times r_{C L A Y H 2 O}+r_{T E R R} \times$ $r_{\text {TERRH2O }}$, where $r_{C H}, r_{C L A Y}$, and $r_{T E R R}$ are mass 
fraction of CH, CLAY, and TERR. This mixing proportion is a free parameter that can be adjusted by the operator to match subducted sediment compositions [Hacker, 2008; Plank and Langmuir, 1998]. The meta-AOC mineral modes $\left(X a_{A O C}\right)$ and dehydration mass fraction $\left(r_{A O C H 2 O}\right)$ are obtained directly from Perple_X; the same is true for PERID $\left(X a_{\text {PERID }}\right.$ and $\left.r_{\text {PERIDH2O }}\right)$ (see Figures 2 and 3 ).

[32] For a given $X a, r_{H 2 O}$ and $D_{\text {minerallfluid, the }}$ dehydrated fluid composition is obtained from the Rayleigh distillation equation [Ayers, 1998].

$X_{F L U I D}=X_{S L A B} \times \frac{1}{D_{S L A B / F L U I D}} \times\left(1-F_{F L U I D}\right)\left(\frac{1}{D_{S L A B / F L U I D}}-1\right)$

where

$$
\begin{aligned}
X_{F L U I D} & \text { fluid composition of an element; } \\
X_{S L A B} & \text { slab composition of an element; } \\
D_{S L A B / F L U I D} & \text { partition coefficient between slab } \\
& \text { and fluid, } D_{S L A B / F L U I D}=\sum_{1}^{n} X_{a} \times D_{a} \\
& \sum_{1}^{n} X_{a}=1 ; \\
X a & \begin{array}{l}
1 \\
\text { modal composition of a residual } \\
\text { mineral in slab; }
\end{array} \\
D a & \text { distribution coefficient of an } \\
& \text { element between fluid and mineral; } \\
F_{F L U I D} & \text { mass fraction of fluid released from } \\
& \text { slab. }
\end{aligned}
$$

[33] The effect of $F_{F L U I D}$ depends on the mass fraction of dehydrated fluid from the slab calculated by Perple_X, but this affects only the dilution of elements in the fluid. This effect of dilution by the Rayleigh model is small when dehydrated fluid mass is less than $10 \%$.

[34] Rayleigh distillation calculations are performed at $0.1 \mathrm{GPa}$ steps from $\mathrm{P}=0.5$ to $6 \mathrm{GPa}$ along a given SST. At $\mathrm{P}<0.5 \mathrm{GPa}(\sim 18 \mathrm{~km}$ depth), fluid evolution from the subducted slab is dominated by the closure of pores and fractures rather than by mineral dehydration [Hacker, 2008] and we do not consider this $P$-T. Temperaturedependent $D_{\text {mineralffluid }}$ values are taken into account in the stepwise calculations. The mass of each element removed from the slab by dehydration at each step modifies the composition of the slab for the next calculation step. This approach is similar to that proposed by Marschall et al. [2007]. Change in the source SED/AOC compositions (Cs SED and Cs AOC) by fluid depletion expressed by remaining fraction of original SED/AOC com- position are shown graphically in SDS worksheet of Software S1. Finally, the slab fluid compositions for a given $P-T$ condition are calculated by mixing the released fluids from SED- $\left(X_{F L U I D} S E D\right)$ and AOC-derived ( $\left.X_{F L U I D} A O C\right)$ with an adjustable mixing parameter $\left(r_{m i x}\right)\left(r_{m i x}=\right.$ mass fraction of SED fluid in total fluid; see SDS module in Figure 2). In nature, this parameter is probably influenced by the amount of fluid dehydration from each component in a closed system; however, we provide $r_{m i x}$ as an adjustable parameter without any geodynamic or petrological constraints because the relative proportions of SED and AOC sources is generally not known. For example, $X_{S E D}$ components are thought to be less than $5 \%$ of fluid mass in the case of Izu-Bonin-Mariana arc basalts [Ishizuka et al., 2003] but is argued to be almost $95 \%$ of the fluid mass in Sunda arc lavas [Sendjaja et al., 2009; Turner and Foden, 2001], even though both arcs are associated with cold subduction zones. Isotope mixing using this same model provides a better constraint.

[35] The $\mathrm{Sr}-\mathrm{Nd}-\mathrm{Pb}$ isotopic compositions of the slab fluids are assumed to be the same as those in the source materials. Slab dehydration is a lowtemperature process, which can fractionate some isotopes. Isotopes used in ABS2 have greater atomic mass $\left({ }^{86} \mathrm{M}^{208} \mathrm{M}\right)$ with relatively small mass difference between isotopes, so significant isotopic fractionation is unlikely. However, isotopes with smaller atomic mass and larger relative mass differences such as Li and B, which are not modeled by ABS2, will fractionate during slab dehydration [Wunder et al., 2005, 2006]. Mixing of $X_{\text {FLUID SED }}$ and $X_{F L U I D} A O C$ is based on isotopic binary mixing [Faure and Mensing, 2005] controlled by element abundances in $X_{F L U I D ~ S E D}$ and $X_{F L U I D ~ A O C}$. Thus, the $r_{\text {mix }}$ between $X_{F L U I D}$ SED and $X_{\text {FLUID AOC }}$ is critical for constraining the isotopic mass balance.

\subsection{Fluid-Mantle Reaction: Two-Stage Zone-Refining Model}

\subsubsection{Zone-Refining Stage 1: Mantle Wedge Sole}

[36] Fluids liberated from the slab should react with the overriding wedge mantle to form hydrous silicates such as amphibole, serpentine, chlorite, and phlogopite. This mantle wedge includes a low- $T$ wedge sole overlain by high- $T$ mantle wedge asthenosphere [Navon et al., 1996; Poli and Schmidt, 1995; Tatsumi and Eggins, 1995] (Figure 1). The subarc mantle may also include lithospheric mantle 
between the arc crust and asthenosphere, but this is not considered in ABS2. Here we focus on processes in the sole; high- $T$ processes in the wedge asthenosphere are considered in section 2.3.2.

[37] The mantle wedge sole is important for arc magma genesis because this is where an important stage of PERID metasomatism occurs because of reaction with infiltrating slab fluid [Bebout, 2007; Garrido et al., 2005; King et al., 2003]. Metasomatized PERID will then be dragged down to dehydrate at higher $P$ [Ionov and Hofmann, 1995; Tatsumi and Eggins, 1995]. Along the NE Japan SST, for example, Perple_X calculations indicate that serpentine is stable to $2.8 \mathrm{GPa}$ and chlorite is stable to $3.5 \mathrm{GPa}$ for PERID (see Figure 3h). Almost no hydrous silicates remain after chlorite breaks down because of the very low $\mathrm{K}$ content of PERID, which prevents stabilization of sheet silicates such as phlogopite.

[38] One problem arises in modeling mass balance in this region: to properly calculate the effects of fluid flux from the slab into the mantle, the rate and pattern of flow within the wedge relative to the slab velocity must be known. Solving this problem requires a dynamic mass balance model and is beyond the scope of this paper. As a simplification, we assume that (1) a metasomatized PERID layer develops above the slab and (2) slab-derived fluid is fully absorbed by the metasomatized PERID layer (indicated by 2.1 in Figure 1). These assumptions may be reasonable because this fluid is unlikely to penetrate beyond the low- $T$ PERID layer until the layer is completely transformed to hydrous silicates. Change in hydrated PERID composition along the slab surface expressed by relative enrichment factor (multiples or fractions of the original PERID composition $\left(X_{\text {PERID }}^{\prime}\right)$ is shown graphically in SDS worksheet of Software S1. Once the PERID layer is saturated, excess fluid can traverse the layer by crack or porous flow. We apply a zone-refining reaction calculation [Ayers, 1998 ] to simulate this fluid-PERID reaction (see the ZR module in Figure 2).

$$
\begin{aligned}
X_{\text {FLUID }}^{\prime}= & \frac{X_{\text {PERID }}^{\prime}}{D_{\text {PERID } / \text { FLUID }}}-\left[\frac{X_{\text {PERID }}^{\prime}}{D_{\text {PRERID } / \text { FLUID }}}-X_{\text {FLUID }}\right] \\
& \times \exp \left(-n \times D_{\text {PERID/FLUID })}\right.
\end{aligned}
$$

where

$$
\begin{array}{ll}
X_{\text {FLUID }}^{\prime} & \begin{array}{l}
\text { reacted fluid composition of an } \\
\text { element; }
\end{array}
\end{array}
$$

\section{$X_{\text {PERID }}^{\prime}$ metasomatized mantle peridotite composition of an element; \\ $X_{F L U I D}$ slab fluid composition of an element derived from equation (1); \\ $D_{\text {PERID/FLUID }}$ partition coefficient of an element between mantle peridotite and fluid, $D_{\text {PERID/FLUIS }}=\sum_{1}^{n} X a \times D a$, $\sum_{1}^{n} X a=1$ \\ $X a$ modal composition of a residual mineral in PERID; \\ $D a$ distribution coefficient of a mineral; \\ $n$ reacted mass of mantle peridotite in multiples of fluid weight; in other words, peridotite-fluid mass ratio.}

[39] A zone-refining reaction is useful for modeling the mantle wedge sole because it can simulate fluid-PERID interactions, ranging from no reaction $(n=0)$ to full reaction ( $n=$ infinity).

[40] To incorporate this model into ABS2, we assume that (1) the slab-derived fluid is added to overlying PERID until the bound $\mathrm{H}_{2} \mathrm{O}$ reaches saturation for a given $P-T$ and (2) this saturation continues along the SST up to $6 \mathrm{GPa}$. In theory, the stepwise fluid addition from the slab results in a significant increase of the metasomatized PERID mass. This mass increase does not affect the zonerefining model, because reaction between the slab fluid and metasomatized PERID is simply defined by the peridotite-fluid mass ratio " $n$."

[41] In contrast to the solid-fluid mass balance issue, the metasomatized PERID composition changes along the SST because of the progressive addition of slab fluids that progressively change composition as the subducted slab experiences prograde metamorphism. The metasomatized PERID composition $\left(X_{\text {PERID }}^{\prime}\right)$ at a given $P-T$ is used for the zone-refining reaction with the slabderived fluid $\left(X_{\text {FLUID }}\right)$ at the same $P$ - $T$ condition. In this case, we assume a 2-D (vertical) reaction column where the fluid derived from the slab rises into the directly overlying PERID where it is involved in zone-refining reactions. The PERID $X a$ is calculated by Perple_X. The $D_{\text {mineralffluid }}$ values used for zone refining are from $\Sigma=X a \times$ $D a$. (see SDS and ZR modules in Figure 2). The calculated compositions of the metasomatized PERID $\left(X_{\text {PERID }}^{\prime}\right)$ and zone-refined fluid $\left(X_{\text {FLUID }}^{\prime}\right)$ are shown in the panel in ZRef_1 worksheet in Software S1. 
[42] The isotopic compositions of metasomatized PERID change in composition along the SST and are calculated by stepwise computations in SDS (see SDS worksheet in Software S1). The isotopic calculations during stage 1 zone refining are basically the same as the equation of Ayers [1998], but use a computational rather an analytical solution (see ZRef_1 worksheet in Software S1). The modified slab-derived fluid composition $X_{F L U I D}^{\prime}$ is used for further reactions higher in the mantle wedge (Figure 2).

[43] An alternative geochemical model for wedge sole hydrous peridotite is dehydration from the progressively metasomatized peridotite. We can apply PERID derived fluid calculated by Rayleigh distillation as one of the fluid components from slab along with slab SED and AOC fluids. One difficulty encountered is mass balance in wedge sole PERID as the model for fluid in this region should include input of fluid from the slab as well as output of fluid to the high temperature mantle wedge. Compared to the slab fluid mass balance governed by outflow from the slab alone, PERID mass balance is difficult to constrain unless total influxes of both PERID and fluid are known. Moreover, the temperature structure in the mantle wedge base is also hard to constrain. To avoid this complexity, we chose a zone-refining model using metasomatized mantle as a reactor to the slab derived fluids although we consider progressive composition change of the PERID by fluid metasomatism.

[44] By applying the wedge base metasomatismstage 1 zone-refining reaction, the effect of the mantle wedge base sole is to add more fluid mobile elements, such as $\mathrm{Rb}, \mathrm{Ba}$, and $\mathrm{K}$, to the slab derived fluid as " $n$ " increases. This means that this process can account for the behavior of other volatile and extremely fluid mobile elements, such as As, $\mathrm{Sb}, \mathrm{Cl}$, F, B, and Li [Bebout et al., 1999; Marschall et al., 2006, 2007; Ryan et al., 1995; Sadofsky et al., 2008; Straub and Layne, 2003; Wunder et al., 2005, 2006]. These elements are not considered in our ABS2 model but modeling them is expected to be a future modification to the ABS model. To do this, information about temperature-dependent mineral/fluid partition coefficients for these elements in the mantle and particularly in the slab are needed.

\subsubsection{Zone-Refining Stage 2: Inside the Mantle Wedge}

[45] The second reaction step in the mantle wedge takes place in the hot asthenospheric core. Ayers
[1998] used his experimental results on element partitioning between fluid and mantle minerals to simulate changes in fluid composition during fluid transfer through mantle peridotite [Ayers, 1998]. The presence of an inverted geotherm in the lower part of the mantle wedge [Peacock et al., 2005] implies that no hydrous silicates other than phlogopite survive in the wedge core [Schmidt and Poli, 1998] (see Figures 3a, 3d, and 3g). Phlogopite can affect only $\mathrm{K}, \mathrm{Ba}$, and $\mathrm{Rb}$ contents [Green et al., 2000] and is not effectively stabilized by low-K PERID. Thus it plays a negligible role for other elements in the mantle wedge asthenosphere. In this scenario, fluids processed by the 1st stage of the zone refining are immediately introduced into the nominally anhydrous mineral bearing PERID system [Iwamori, 1998, 2000]. In this part of the wedge, little modification of the fluid element abundances occurs until it reaches the peridotite melting region, except for elements such as $\mathrm{Y}, \mathrm{Zr}$, or Th which are partitioned into nominally anhydrous mantle minerals [Ayers, 1998].

[46] For the 2nd stage zone-refining reaction in the mantle wedge, ABS2 uses Ayers's [1998] zonerefining model, producing $X_{F L U I D}^{\prime \prime}$, which is available for further reaction (Figure 2). This module (ZR2) has the same calculation steps as the 1st stage zone refining (ZR1), but with different $D$ values. The calculated compositions of unmetasomatized PERID $\left(X_{P E R I D}\right)$, the zone-refined fluid $\left(X_{\text {FLUID }}^{\prime \prime}\right)$ compositions, and bulk rock partition coefficients are shown in ZRef 2 worksheet in Software $\mathrm{S} 1$. Note that the $\mathrm{Sr}-\mathrm{Nd}-\mathrm{Pb}$ isotopic composition of PERID is predefined as the source component of ABS 2. This composition is modified by wedge sole metasomatism during 1 st stage zone refining, whereas the original PERID composition is used for 2 nd stage zone refining. In the 2nd stage, fresh PERID is assumed to be supplied by convective flow of the mantle from behind the arc (see Figure 1).

[47] The zone-refining reactions of ZR1 and ZR2 simulate an extremely wide range of reactions with chromatographic element behavior (see sigmoidal curves in Figure 5). The reaction of the slab fluid increases with increasing " $n$." The effect depends on $D_{P E R I D / F L U I D}$, where elements with low $D_{\text {PERID/FLUID }}$ are largely preserved in fluids up to large " $n$ " (see $\mathrm{Pb}$ in Figure 5 (top)). Assuming that $D\left(\mathrm{H}_{2} \mathrm{O}\right)_{\text {PERID/FLUID }}$ is equal to $D(\mathrm{Ce})_{\text {PERID/FLUID }}$ [Stolper and Newman, 1994], the behavior of aqueous fluid can be investigated. Up to $n=1$, almost all the $\mathrm{H}_{2} \mathrm{O}$ in fluid is derived from the slab, 

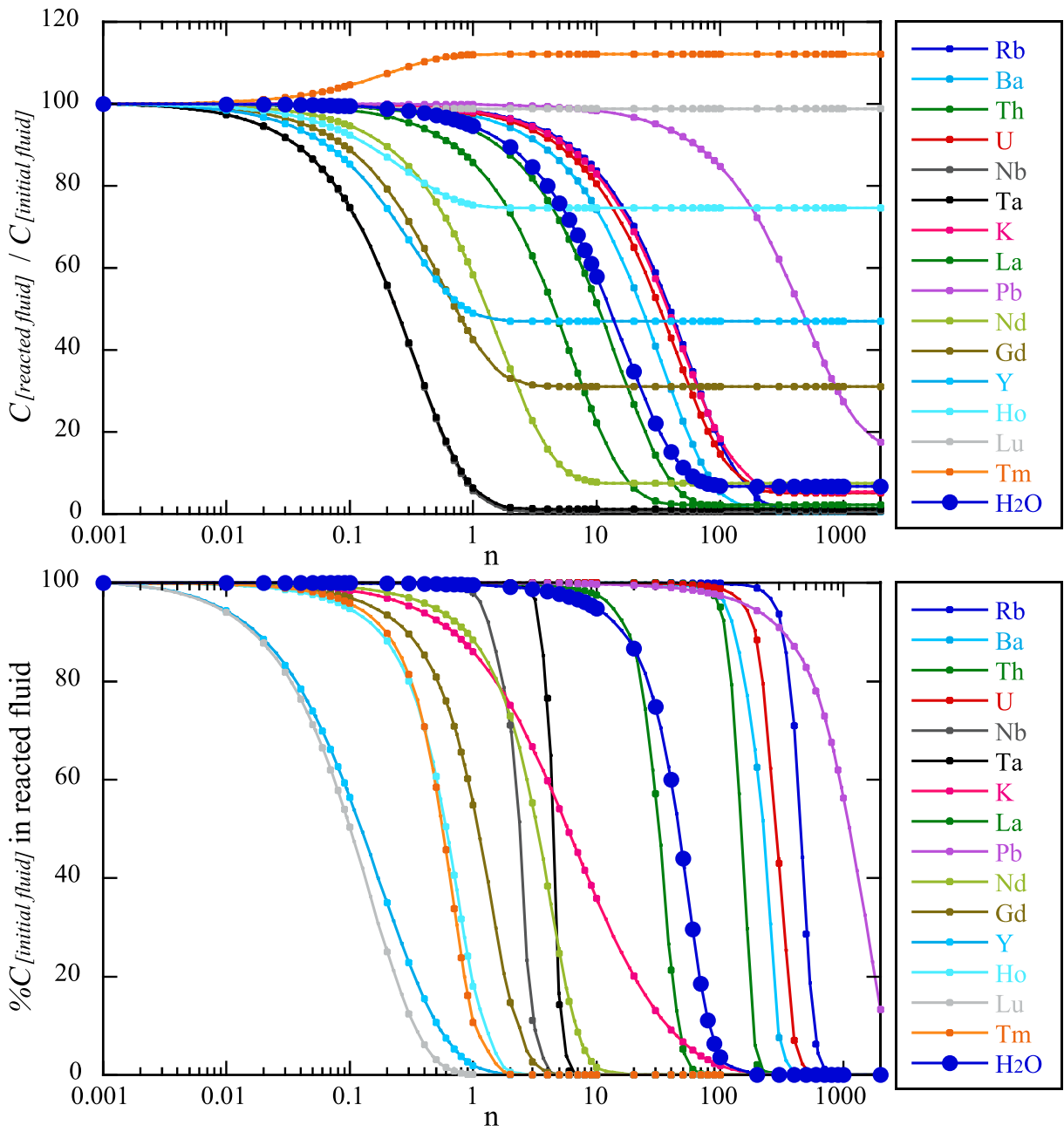

Figure 5. Element behavior as a result of second-stage zone-refining reactions. (top) Composition of the final fluid relative to the original fluid. (bottom) Percent of the original slab-derived element flux that is retained in fluid. This is equal to isotopic ratio changes with increasing $n$. Note that element abundance and $\%$ original element flux changes describe sigmoidal curves, which depend on partition coefficient $D_{\text {fluid/peridotite }} . \mathrm{H}_{2} \mathrm{O}$ is simulated using $D \mathrm{H}_{2} \mathrm{O}=D C$. $\mathrm{H}_{2} \mathrm{O}$ in fluid is almost $100 \%$ from slab-derived fluid up to $n \sim 1$ but is replaced by $\mathrm{H}_{2} \mathrm{O}$ from nominally anhydrous peridotite minerals at $n \sim 100$. The zone-refining model can simulate a wide range of fluid-peridotite interactions, ranging from $n=0$ (fluid moves along cracks with no interaction with peridotite) to $n \sim$ infinity (porous flow and chromatographic reaction and complete reequilibration).

whereas at $n \sim 100$, the slab-derived $\mathrm{H}_{2} \mathrm{O}$ is replaced by $\mathrm{H}_{2} \mathrm{O}$ from nominally anhydrous PERID $\left(\mathrm{H}_{2} \mathrm{O} \sim\right.$ $0.3 \%$ [ Iwamori, 2000]) (Figure 5, bottom).

\subsection{Mantle Melting: $\mathrm{P}-\mathrm{T}-\mathrm{XH}_{2} \mathrm{O}-\mathrm{F}$ Constrained Open System Fluid-Fluxed Melting}

[48] The third box of ABS2 describes the mantle melting (OSM in Figure 2) using an open system dynamic melting equation [Ozawa, 2001; Ozawa and Shimizu, 1995; Zou, 1998]. The equation that we used is that of Zou [1998] for partial melting of the mantle (calculations for residual solid and interstitial melt compositions are included but not used for ABS2, see OSM worksheet in Software S1), but is basically the same as that proposed by Ozawa and Shimizu [1995]. The equations require input of the slab fluid composition $\left(X_{F L U I D}^{\prime \prime}\right)$, mantle peridotite composition $\left(X_{P E R I D}\right)$, and variables for melting conditions. The melting parameters include the partition coefficients between peridotite and hydrous melt $\left(D_{\text {SOLID/MELT }}\right)$, mantle-melting mineralogy $(\mathrm{Xa}$ and $\mathrm{Pa})$, degree of partial melting $(F)$, porosity (residual melt mass fraction after melt extraction) of the melting system $(\phi)$, and mass fraction of fluid in generated melt (note that the definition of $\beta$ is given as "fluid mass fraction of initial solid divided by degree of melting $F$ " by assuming constant fluid flux to the melting system 
[Ozawa and Shimizu, 1995]) ( $\beta$ ) (see Figure 2). $X_{\text {FLUID }}^{\prime \prime}$ is derived from the zone-refining (ZR) module as noted above, $X_{P E R I D}$ uses a depleted MORB mantle composition [Salters and Stracke, 2004; Workman and Hart, 2005] with variously depleted compositions at $X_{P E R I D}$, the same as that used for the wedge sole PERID and wedge core PERID. mantle PERID. This means that $\beta$ is the $\mathrm{H}_{2} \mathrm{O}$ mass fraction in the melt just prior to melt extraction defined by Shaw [2000, equation (22)] if the fluid flux rate is constant [Ozawa and Shimizu, 1995]. There is a strong constraint on the relation between $\mathrm{T}-\mathrm{P}-\mathrm{XH}_{2} \mathrm{O}$ and $\mathrm{F}$ during partial melting. The degree of melting, $F$, is a well-known function of $T$ and $P$ [Green, 1973;

$$
\begin{aligned}
X_{B A S}= & \frac{1}{F-F C} \cdot \frac{1}{P-\beta-1} \\
& \times\left\{\begin{array}{l}
X_{F L U I D}^{\prime \prime} \cdot \beta \cdot(F c-F) \\
+\left\{\frac{\left[X_{F L U I D}^{\prime \prime} \cdot \beta \cdot D+X_{P E R I D} \cdot(P-\beta-1)\right] \cdot[D+\alpha-F C \cdot(\alpha+P)]}{[D+F C \cdot(1+\beta-P)] \cdot(\alpha+\beta+1)}\right\} \\
\times\left\{1-\left[\frac{D+\alpha-F \cdot(\alpha+P)}{D+\alpha-F C \cdot(\alpha+P)}\right]^{[(1+\beta-P)}{ }_{(\alpha+P)}\right]+1
\end{array}\right\}
\end{aligned}
$$

where

$X_{B A S}$ basalt melt composition of an element;

$X_{P E R I D}$ source peridotite composition;

$D$ bulk melt distribution coefficient of an element determined by $D=\sum_{1}^{n} X a \times D a$, $\sum_{1}^{n} X a=1$

$X a$ modal composition of a residual mineral phase;

$D a$ melt distribution coefficient of a mineral;

$P$ contribution of consumed mineral, $P=$ $\sum_{1}^{n} P a \times D a, \sum_{1}^{n} P a=1 ;$

$\mathrm{Pa}$ modal composition of a consumed mineral;

Da melt distribution coefficient of a mineral;

$\alpha$ interstitial melt weight volume determined by $\alpha=\phi /(1-\phi)$;

$\phi$ porosity of melting system or residual melt mass fraction after melting;

$\beta$ mass fraction of fluid in generated melt (when fluid influx is constant);

$F$ degree of partial melting;

$F c$ defined by $\alpha /(\alpha+\beta+1)$;

$X_{\text {FLUID }}^{\prime \prime}$ fluid composition calculated by equation (2).

[49] In a fluid-fluxed melting system, one should consider the affect of $\mathrm{H}_{2} \mathrm{O}$ added to the system, which controls degree of melting at a given $P-T$ condition [Grove et al., 2006; Hirose and Kawamoto, 1995; Katz et al., 2003]. The open system melting model uses $F$ and $\beta$, defined as $\beta=\mathrm{XH}_{2} \mathrm{O} / \mathrm{F}$, where $\mathrm{XH}_{2} \mathrm{O}$ is the mass fraction of $\mathrm{H}_{2} \mathrm{O}$ in the
Kushiro, 1996] and $\mathrm{H}_{2} \mathrm{O}$ [Grove et al., 2006; Hirose and Kawamoto, 1995]. A parameterization of $\mathrm{P}-\mathrm{T}-\mathrm{XH}_{2} \mathrm{O}-\mathrm{F}$ relation consistent with experimental results was proposed by $\mathrm{Katz}$ et al. [2003]. Realistic modeling of open system, fluid flux melting requires parameterization of $P-T$ $\mathrm{XH}_{2} \mathrm{O}-\mathrm{F}$. We applied the Katz et al. [2003] parameterization with a computational solution of Katz et al. [2003, equation (19)] (see "Katz" worksheet in Software S1). The amount of clinopyroxene in PERID also controls $F[$ Katz et al., 2003]. The clinopyroxene mode is derived from the mineralogic mode of PERID estimated by pMELTS at various \% $\%$ MRB extract as described above in the OSM worksheet (Software S1).

[50] The input parameters constraining open system melting are $\mathrm{P}, \mathrm{T}$, and $\mathrm{XH}_{2} \mathrm{O}$. At a given $\mathrm{P}-\mathrm{T}-\mathrm{XH}_{2} \mathrm{O}$ $\mathrm{XH}_{2} \mathrm{O}$ condition, the Katz module of ABS2 calculates $F$ and the mass of $\mathrm{H}_{2} \mathrm{O}$ dissolved in the melt. We use this dissolved $\mathrm{H}_{2} \mathrm{O}$ as a quasi-equivalent fluid flux $(\beta)$. The $F$ and $\beta$ thus obtained are used by the open system melting model to calculate the trace element composition of the melt (see OSM worksheet in Software $\mathrm{S} 1$ ). The $\mathrm{H}_{2} \mathrm{O}$ saturation of the melt is another important limitation. Once the melt is saturated with $\mathrm{H}_{2} \mathrm{O}$, additional $\mathrm{H}_{2} \mathrm{O}$ should migrate out of the melting system as a separate phase, and $F$ cannot increase further. Such a limitation is considered in the ABS2 calculations; model results for water-oversaturated melts are excluded, using thresholds determined by the $P$-dependent $\mathrm{H}_{2} \mathrm{O}$ saturation curve of Katz et al. [2003].

[51] The residual melt mass fraction (or porosity) is set at $\phi=0.01-0.03$ (usually 0.01 ) as estimated from geophysical constraints in the mantle 
wedge above the cold NE Japan subduction zone [Nakajima et al., 2005]. $\mathrm{Xa}$ and $\mathrm{Pa}$ are derived from pMELTS calculations for a range of $P$ and $F$ [Ghiorso et al., 2002] on a DMM mantle composition [Workman and Hart, 2005]. Mineral modes of $X a$ at $1-3 \mathrm{GPa}(0.1 \mathrm{GPa}$ step) and $F$ at $1-30 \%$ ( $1 \%$ step) melting are available (see Per_Mode worksheet in Software S1). $P a$ is poorly constrained by pMELTS at low $F$, so we set $P a=X a$ (modal melting). This does not greatly affect the calculated trace element compositions except for extremely low $F$ of garnet-bearing residue [Kimura and Yoshida, 2006]. D $D_{\text {SOLID/MELT }}=$ $\Sigma X a \times D_{\text {minerallmelt }}$ is calculated using $D_{\text {minerallmelt }}$ from Green et al. [2000]. One can also test different partition coefficients $D_{\text {mineral/melt }}$ [e.g., McDade et al., 2003a, 2003b; Salters et al., 2002] by altering partition coefficient in the Data_Input panel (see Software S1). The trace element composition of high $\mathrm{Mg}$ \# basalt $\left(X_{B A S}\right)$ is eventually calculated (see OSM worksheet in Software S1). The isotopic compositions of $X_{B A S}$ are calculated using a computational solution of the OSM equation (see IOSM worksheet in Software S1).

[52] Note that all the dehydration, zone refining, and open system melting parameters above are given as mass fractions in equation (1) to equation (3) and in Katz et al.'s [2003] parameterization equations. However, we use mass fraction expressed on a 100 percent basis in the fitting parameters of ABS2 $\left(\%\right.$ MORB extraction, $\% \mathrm{XH}_{2} \mathrm{O}$, $\% F, \% \beta$, and $\% \phi$ ). These parameters are listed for convenience in Appendix A.

\subsection{ABS2 Model Summary}

[53] Absolute mass balance during open system melting is fully maintained among fluid, PERID, and melt in terms of elements and isotopes. In contrast, the masses of dehydrated slab fluid, fluid and peridotite that contributed to zone-refining reactions in stages 1 and 2 are treated as ratios rather than absolute mass fractions. This basic scheme of the ABS2 model, thus, uses relative contributions of (1) slab SED/AOC, (2) metasomatized PERID, and (3) high-temperature PERID in the mantle wedge to the fluid composition that is eventually introduced to the open system melting. This means that once entire agreement is achieved between model and natural high $\mathrm{Mg}$ \# basalts, contributions of (1) slab $P$-T, thus element abundances in the slab fluid calculated via $T$-dependent $D_{\text {fluid/mineral }}$; (2) mass fractions between SED and AOC fluids; and (3) mass ratio between fluid and
PERID defined by " $n 1$ " and " $n 2$ " should all be satisfied to fit the fluid composition introduced into the open system melting.

[54] The three calculation modules (SDS, twostage ZR, OSM) of ABS2 are sequentially connected with the Data Input module (Figure 2). The parameters described above are linked between modules. The constraints from the calculation steps are interlinked without iterating. Therefore, the overall ABS2 model consists of a series of forward calculations: (1) the source composition input, (2) the SDS calculator of slab fluid composition, (3) the zone-refining fluid-mantle reaction, and (4) open system melting (Figure 2). The unknown variables are intensive and extensive parameters (e.g., $\mathrm{P}, \mathrm{T}, \% \mathrm{XH}_{2} \mathrm{O}, r_{\text {mix }}$, and " $n$ " factors). The mass balance calculations are performed for 26 incompatible elements and $\mathrm{Sr}-\mathrm{Nd}-\mathrm{Pb}$ isotopic compositions. A full mass balance is maintained in the three isotope systems as well as trace elements using nonanalytical computational solutions in the isotope calculations in the SDS, ZR, and OSM modules. This is one of the major advantages of $\mathrm{ABS} 2$ for understanding primitive arc basalts, as the calculation sequence is basically a forward model that can be iteratively fitted to data by varying input parameters. Automated fitting is partially available using macro function of Excel ${ }^{\mathbb{R}}$, as described in section 3.3.

\section{Using the ABS2 Excel ${ }^{\circledR}$ Spreadsheet}

\subsection{Excel ${ }^{\circledR}$ ABS Version 2 Structure}

[55] ABS2 is a Microsoft $\odot$ Excel $^{\circledR}{ }^{\mathbb{}}$-based program (Software S1) that uses 14 different worksheets in an Excel file. The user interface consists of three worksheets: (1) Control_Panel, (2) Data_Input, and (3) Result_Comp. The Data_Input worksheet is a spreadsheet for inputs of source compositions $\left(X_{C H}, X_{C L A Y}, X_{T E R R}\right.$, and $\left.X_{A O C}\right)$, normalization values for multielement plots, and PERID-melt partition coefficients for olivine, clinopyroxene, orthopyroxene, spinel and garnet (Software S1).

[56] The Control_Panel worksheet (Figure 6) has input cells that control input variables discussed above (see also parameters in blue in Figure 2) as defined in Appendix A. The other 11 worksheets are separate calculation modules: (4) the Per_Dep worksheet calculates depleted PERID source composition at various \% \%ORB extract; (5) the Slab_ Mode worksheet and (6) the SDS worksheet combine to form the SDS module, which calculates mineralogic modes and bound $\mathrm{H}_{2} \mathrm{O}$ contents along 


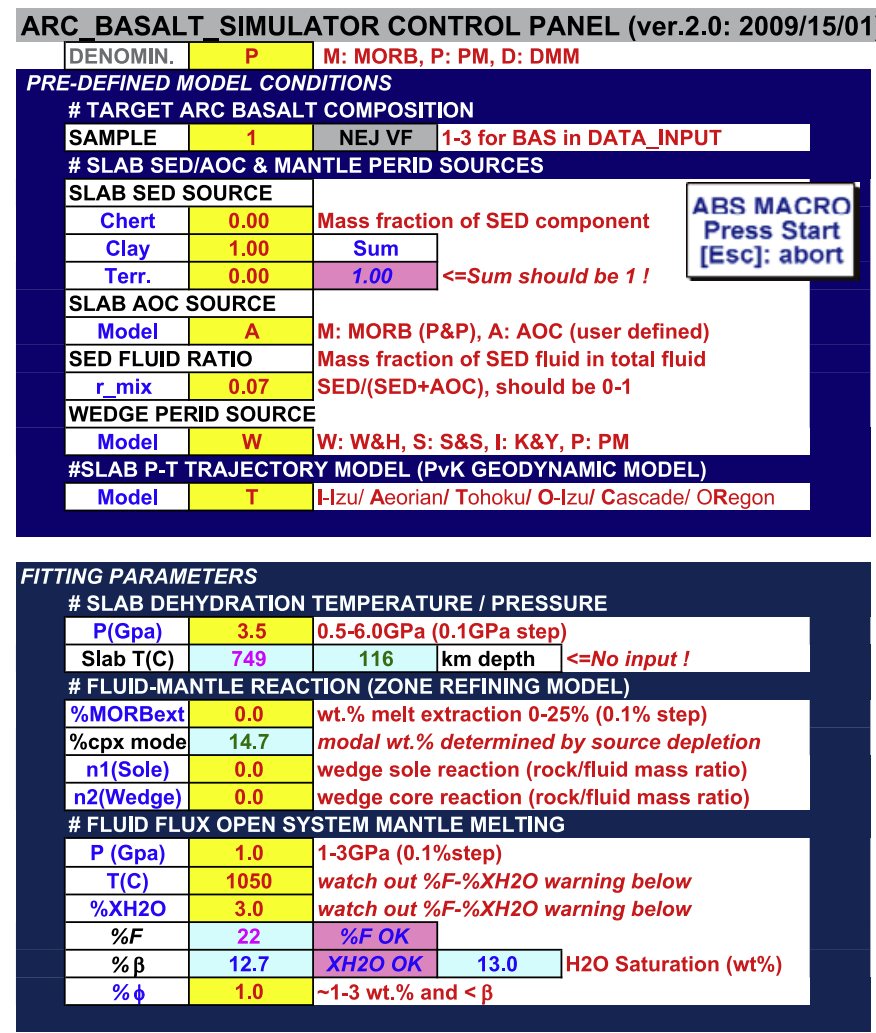

\begin{tabular}{|c|c|c|c|c|c|}
\hline \multicolumn{4}{|c|}{ SLAB MINERALOGY } & \multicolumn{2}{|c|}{ MANTLE MINERALOGY } \\
\hline SOURCE & $A O C$ & SED & PERID & SOURCE & PERID \\
\hline $\mathrm{H} 2 \mathrm{O}$ (wt.\%) & 0.077 & 1.585 & 0.000 & $\mathrm{H} 2 \mathrm{O}$ (wt.\%) & 3.000 \\
\hline Gar & 0.451 & 0.139 & 0.139 & OI & 0.750 \\
\hline Cpx & 0.424 & 0.343 & 0.114 & Opx & 0.207 \\
\hline Ol & 0.000 & 0.000 & 0.601 & Cpx & 0.000 \\
\hline Opx & 0.000 & 0.000 & 0.145 & Gar & 0.000 \\
\hline $\mathrm{SiO2}$ & 0.091 & 0.120 & 0.000 & Sp & 0.043 \\
\hline Plag & 0.000 & 0.000 & 0.000 & Sum & 1.000 \\
\hline Chl & 0.000 & 0.000 & 0.000 & & \\
\hline Bio & 0.000 & 0.000 & 0.000 & \multicolumn{2}{|c|}{ FLUID COMPOSITION } \\
\hline Phen & 0.021 & 0.393 & 0.000 & $\Sigma$ (trace) $\%$ & 1.49 \\
\hline Amp & 0.000 & 0.000 & 0.000 & & \\
\hline Serp & 0.000 & 0.000 & 0.000 & \multicolumn{2}{|c|}{ BASALT COMPOSITION } \\
\hline PhA & 0.000 & 0.000 & 0.000 & $\mathrm{H} 2 \mathrm{O}$ (wt.\%) & 7.7 \\
\hline Law & 0.000 & 0.000 & 0.000 & & \\
\hline Zo & 0.000 & 0.000 & 0.000 & & \\
\hline TiO2 & 0.013 & 0.005 & 0.001 & & \\
\hline Sum & 1.000 & 1.000 & 1.000 & & \\
\hline
\end{tabular}
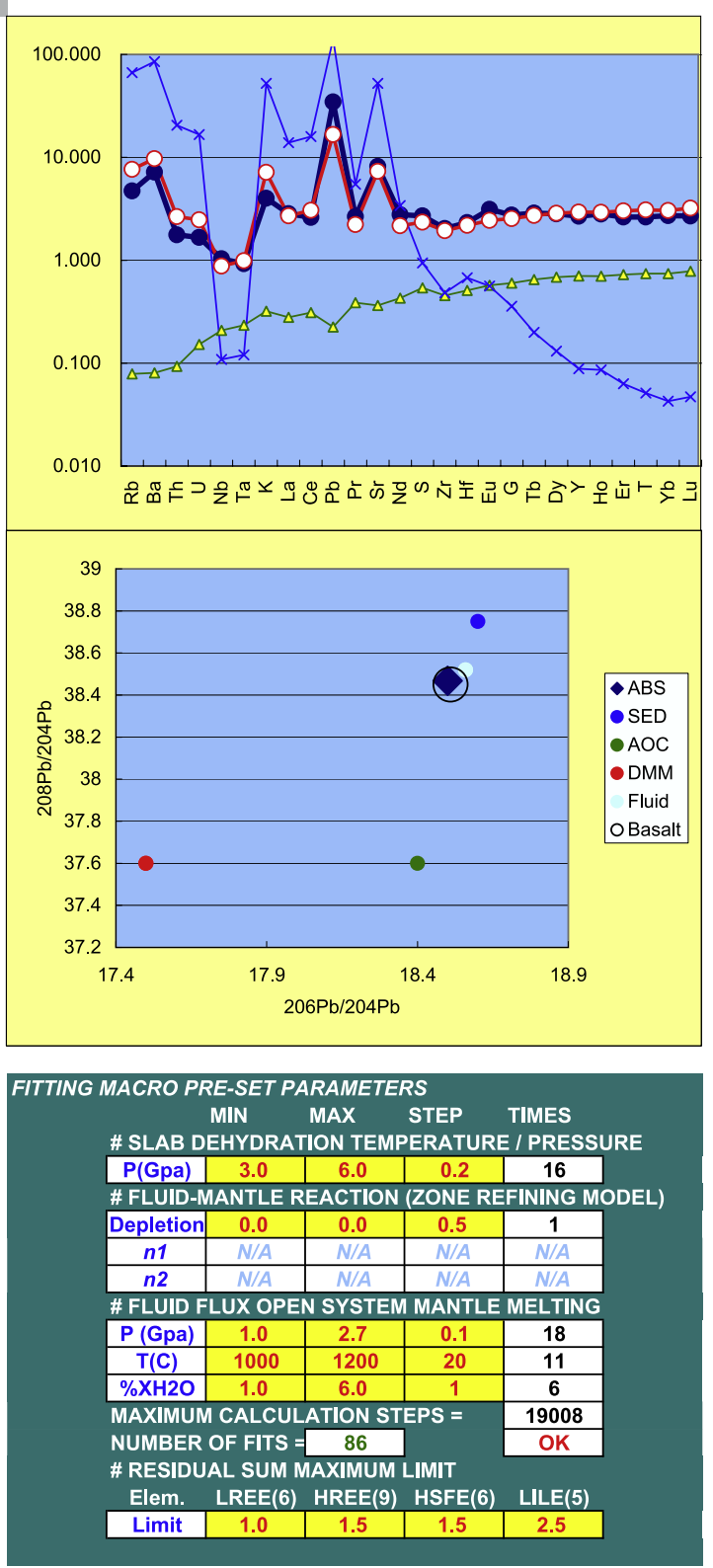

Figure 6. ABS version 2 Control_Panel worksheet. Predefined model conditions panel includes parameters for altering source compositions (e.g., $\overline{\mathrm{CH}}$, CLAY, and TERR), mixing ratio $=r_{S E D}$, and mantle wedge PERID model (either PM, primitive mantle; W, Workman and Hart [2005] DMM; or S, Salters and Stracke [2004] DMM). SST model can be set to one of several subduction zone thermal models. Fitting parameters panel defines $P_{S D S}$ slab dehydration pressure along the SST, \% ${ }_{M O R B}$ extract PERID depletion factor, $n 1$ and $n 2$ zone-refining parameters, $P_{\mathrm{OSM}^{-}} \mathrm{T}_{\mathrm{OSM}^{-}} \mathrm{XH}_{2} \mathrm{O}$, and $\% \phi$ mantle melting parameters used for open system melting parameterization to derive $\% F$ and $\% \beta$. Fitting macro preset parameters panel defines ranges and steps for parameters. Threshold of total residual sum at residual sum maximum limit is entered by the user. Slab mineralogy, mantle mineralogy, fluid composition, and basalt composition panel indicates dehydration mode and wt \% bound $\mathrm{H}_{2} \mathrm{O}$ for the SED, AOC, and PERID components and the mantle-melting mode; the total trace element composition of the fluid and the $\mathrm{H}_{2} \mathrm{O}$ in generated in primitive basalt are also specified. Multielement plot and isotope plot are used for fitting by examination. Note that MORB and OIB dots in element ratio diagrams in Control_Panel of Software S1 are from the Geochemistry of Rocks of the Oceans and the Continents database (Max-Planck-Institut für Chemie, 2007, http://georoc.mpchmainz.gwdg.de/georoc/), and model dots are calculated for Hawaii tholeiite and alkali basalts on the basis of Kimura et al. [2006]. 
the SST (Slab_Mode worksheet) and then calculates slab and slab fluid compositions along the SST with temperature-dependent $D_{\text {minerallfluid }}$ (SDS worksheet); (7) the ZRef_1 and (8) ZRef_2 worksheets calculate zone-refining reactions at the wedge sole and in wedge core mantle peridotite, respectively; and the (9) Per_Mode, (10) Katz, (11) OSM, and (12) IOSM worksheets together form an open system melting module that calculates residual peridotite modes (Per_Mode), $P-T-X_{2} \mathrm{O}-\mathrm{F}$ parameterization (Katz), and open system melting for trace elements (OSM) and isotopes (IOSM). (13) The Rs worksheet calculates key element ratios that are used for diagrams in the Control_Panel worksheet and (14) the Summary worksheet for fitting calculation data output. The diagrams include multielement plot, $\mathrm{Sr}-\mathrm{Nd}-\mathrm{Pb}$ isotope plots, and some key trace element ratios [Pearce et al., 2005]. The denominators of the multielement plot can be altered between primitive mantle PM [Sun and McDonough, 1989], DMM [Workman and Hart, 2005], and N-MORB [Albarède, 2005; Pearce and Parkinson, 1993] by altering the DENOMIN parameter in the Control_Panel worksheet (Figure 6).

\subsection{Control_Panel Unknown Parameters}

[57] Unknown parameters in the Control_Panel are defined in Appendix A. As shown in the predefined model conditions on the Control_Panel worksheet (Figure 6), the unknown variables to be estimated in the 1st stage are the source sediment mixing ratio $\left(r_{S E D}: r_{C H}, r_{C L A Y}, r_{T E R R}\right)$ between $\mathrm{CH}$, CLAY, and TERR $\left(r_{C H}+r_{C L A Y}+r_{T E R R}=1\right.$ giving source SED composition $X_{S E D}=r_{C H} \times X_{C H}+$ $r_{C L A Y} \times X_{C L A Y}+r_{T E R R} \times X_{T E R R}$. $)$ and the wedge peridotite depletion from DMM (\% $\%_{M O R B}$ extract $)$. The released SED slab fluid mass fraction $\left(r_{\text {mix }}\right)$ over total fluid mass between SED and AOC fluids is the only remaining variable in SDS when the SST is defined. For the SST, Tohoku (T), Aeolian (A), Cascade (C), Oregon (R), and two Izu models with isoviscous (I) and with temperature-dependent olivine $(\mathrm{O})$ rheology are provided. The Izu, Tohoku, and Aeolian arcs are cold subduction zones, whereas the Cascadia and Oregon arcs represent hot subduction zones. The SST module will be extended to subduction zones worldwide in the near future (E. Syracuse et al., A global comparison of the thermal structure of subduction zones, manuscript in preparation, 2009). All parameters should be entered, following instructions on the Control_Panel.
[58] The variables shown in the fitting parameters on the Control_Panel are used for the 2nd-stage data fitting. The slab dehydration pressure $\left(P_{S D S}\right)$ defines the slab dehydration $P-T$ conditions along the SST. When the pressure is specified, the $T_{S D S}$ and slab depth are automatically calculated on the basis of the chosen SST. The source PERID depletion (\%MORB extract) should be input in the 1st stage; this parameter is critical for determining other intensive variables, such as the degree of mantle melting $F$. Therefore, this is included in the 2nd stage parameter as the PERID "\%MORBext" factor. The subsequent zone-refining (ZR) variables are $n 1$ and $n 2$ for the two reaction modules. Open system melting (OSM) requires the pressure $\left(P_{\mathrm{OSM}}\right)$, temperature $\left(T_{\mathrm{OSM}}\right)$, and $\% \mathrm{XH}_{2} \mathrm{O}$ of the melting mantle mass, which determine the degree of melting $\% F$ and the mass fraction of fluid in the basalt melt $\% \beta$ in OSM from Katz et al.'s [2003] $P-T-F-X_{2} \mathrm{O}$ parameterization. The residual mass fraction (or porosity) $\% \phi$ is also a parameter of OSM and is usually fixed at $1-3$ as discussed earlier.

\subsection{Data Fitting: Manual Input and Semiautomated Macro Operations}

[59] Fitting between a given primitive basalt composition and the model compositions is available by manually altering the predefined parameters and fitting parameters in the Control Panel (see Figure 6). The operator can alter these parameters from top to bottom (1st stage to 2 nd stage) and find the "best fit" by observing the multielement plot, isotope plots, and element ratio plots on the Control_Panel. Petrologically "acceptable numbers" [Kimura and Yoshida, 2006] can help guide this procedure. Guidance is provided by warning cells immediately right of the calculated $\% F$ and $\% \beta$ cells.

[60] ABS2 includes a macro that semiautomatically finds the best fitting parameters. The Summary worksheet shows the resulting fits. Because of the large number of variables and the underlying complex calculations, it is not always useful to try to fit all parameters. Therefore, the macro fits only the 2nd stage parameters: slab dehydration pressure $\left(P_{S D S}\right)$, PERID depletion $\left(\%_{M O R B}\right.$ extract $)$, and peridotite melting pressure, temperature, and fluid flux ( $P_{\mathrm{OSM}}, \mathrm{T}_{\mathrm{OSM}}$, and $\mathrm{XH}_{2} \mathrm{O} \%$ ). These can be set in the fitting parameters boxes. Two zone-refining parameters $(n 1$ and $n 2)$ and porosity $(\phi \%)$ are treated as predefined parameters because of significant uncertainties. 
[61] The macro calculation parameters are defined in the fitting macro preset parameters panel in the Control_Panel. The ranges and steps of the fitting parameters can be set (see Figure 6). The maximum for the residual sums for LREE (6 elements), HREE (9), HFSE including U and Th (6), and the LILE including $\mathrm{Sr}$ (5), are used for filtering "matched" results to be saved in the Summary worksheet. If the operator wishes to record all the calculation results in each cycle, the maximum residual values should be increased to $\sim 10$ (equivalent of $\pm 100 \%$ threshold of element abundance in total residual sum for 5-9 elements). Restricting the fitting parameter ranges and steps helps reduce calculation cycles and thus time. The maximum recordable calculation cycle is 65,000 , because of the limitation of Excel ${ }^{\circledR}$ 's Summary function. To run the macro, the operator should click the ABS Macro button in the predefined condition field (left of the multielement plot) or use Excel ${ }^{\mathbb{R}}$ commands to run the macro named "parameters." The macro function must be activated when opening the ABS2 following the Excel $^{\mathbb{R}}$ alert.

\section{Application of ABS2: NE (Tohoku) Japan Example}

[62] As an example of how to apply ABS2, we examine the NE Japan arc. The geochemistry of high $\mathrm{Mg}$ \# basalts across the arc has been investigated with the prototype ABS and ABS version 1 [Kimura and Stern, 2009; Kimura and Yoshida, 2006]. High-resolution geophysical images of the mantle wedge [Hasegawa et al., 1991; Nakajima and Hasegawa, 2003; Nakajima et al., 2005] and high-resolution finite element models [Kneller et al., 2007] are available for constraining aspects of the subduction zone. Below we examine two representative high $\mathrm{Mg}$ \# basalts from the volcanic front (VF) and rear arc (RA) of the NE Japan arc [Kimura and Stern, 2009; Kimura and Yoshida, 2006] using ABS2.

\subsection{Source Material and High Mg \# Basalt Data}

[63] The Data_Input worksheet has two major fields of input cells for 26 trace elements $(\mathrm{Rb}$ to $\mathrm{Lu}$ in $\mathrm{ppm}$ ) and $\mathrm{Sr}-\mathrm{Nd}-\mathrm{Pb}$ isotope ratios. The "Target basalt composition" accepts three different basalt compositions $\left(X_{B A S} 1-3\right)$ for simulation (see examples NEJ VF and NEJ RA in Data_Input worksheet in Software S1 for primitive NE Japan arc basalts of Kimura and Yoshida [2006]) and choices made by entering numbers in the SAMPLE cell in the Control_Panel worksheet. The "source composition" field in Data_Input should be entered in the order $X_{A O C}, X_{C H}^{-}, X_{C L A Y}$, and $X_{T E R R}$. Examples in Software S1 are altered MORB [Kelley et al., 2003], and terrigeneous SED with upper continental crust (UCC) composition [Taylor and McLennan, 1985]. As CH and CLAY are not involved, these columns are left blank and their proportions listed in the Control_Panel should be zero. These can be altered using compositions from other databases [Plank and Langmuir, 1998]. The reason why we chose UCC rather than the Pacific sediment is that the NE Japan arc has an accretionary prism and terrigeneous sediments from the arc crust are likely to be subducted. This reason was given by Kimura and Yoshida [2006] and we follow the same model here.

[64] The Perple X calculation in ABS2 is based on $\mathrm{CH}$, CLAY, TERR, and AOC compositions of Hacker [2008]. Other sediment compositions would require additional Perple_X calculations. However, the uniformity of $\mathrm{CH}$, CLAY, TERR, and AOC major element compositions [Staudigel et al., 1996; Taylor and McLennan, 1985] allows broad application of ABS2 with the existing SDS database. We used TERR and AOC compositions for the NE Japan calculations.

\subsection{Fitting ABS2 Output to the NE Japan Basalts}

[65] The Control_Panel (Figure 6) shows an example of manual fitting by examination. The data used for this example are for NEJ VF Funagata basalt analyzed and primary magma compositions estimated by Kimura and Yoshida [2006]. The SST model used is Tohoku ( $\mathrm{T}$ ) (NE Japan) with a temperature-dependent olivine rheology [van Keken et al., 2002]. The result indicates a very good fit using $r_{\text {mix }}=0.07$ for fluid from a slab dehydration depth $P_{S D S}=3.5 \mathrm{GPa}(\sim 116 \mathrm{~km}$ slab depth), and $T_{S D S}=749^{\circ} \mathrm{C}$ slab temperature (see Figure 6). The PERID model is the DMM of Workman and Hart [2005] with no further depletion by melt extraction $\left(\%_{M O R B}\right.$ extract $\left.=0\right)$. No metasomatism of the mantle source is assumed although slab-derived materials obviously affect mantle beneath arcs [Hochstaedter et al., 2001; Pearce et al., 2005] and back arc basins [Kelley et al., 2006; Taylor and Martinez, 2003]. In this context, the arc signature in the primary basalt is fully attributed to the contemporaneous slab fluid. Therefore, the model estimates a maximum role for 
slab derived fluid. In reality, the role of slab fluid is likely less than the model estimates because of the likelihood of earlier episodes of mantle metasomatism. Zone-refining reactions are not necessary, similar to the previous conclusions of Ayers [1998]. The mantle melting conditions are set at $P_{O S M}=1.0 \mathrm{GPa}$ and $T_{O S M}=1050^{\circ} \mathrm{C}$ with $\% \mathrm{XH}_{2} \mathrm{O}=3.0$ wt $\%$ mantle mass, resulting in $\% F=22 \%$ melting with $\% \beta=12.7$ wt $\% \mathrm{H}_{2} \mathrm{O}$ in the basalt melt. This is close to $\mathrm{H}_{2} \mathrm{O}$ saturation of basalt melt at this $P-T$ condition (see Figure 6). Fitting using key trace element ratios is also shown in Software S1 Control_Panel for $\mathrm{Ba} / \mathrm{Yb}, \mathrm{Nb} / \mathrm{Yb}$, $\mathrm{Ta} / \mathrm{Yb}, \mathrm{Th} / \mathrm{La}$, and $\mathrm{Sm} / \mathrm{La}$. Other element pairs are also available from the Result_Comp worksheet.

[66] As one of the predefined model conditions, $r_{\text {mix }}$ is adjusted on the basis of isotopic compositions. The use of the ${ }^{208} \mathrm{~Pb} /{ }^{204} \mathrm{~Pb}-{ }^{206} \mathrm{~Pb} /{ }^{204} \mathrm{~Pb}$ system along with $\mathrm{Sr}-\mathrm{Nd}$ isotope systematics is extremely useful when the target basalt composition lies within the triangular space defined by $X_{S E D}, X_{A O C}$, and $X_{\text {PERID }}$ compositions in ${ }^{208} \mathrm{~Pb} /{ }^{204} \mathrm{~Pb}-{ }^{206} \mathrm{~Pb} /{ }^{204} \mathrm{~Pb}$ space (see Figure 6). The fitting parameters are then altered either by examination or by macro calculations by observing manually or statistically best fit element abundances between natural and model primitive basalts compositions. This was done first with " $n=0$ " inputs in $n 1$ and $n 2$ and then adjusted with $n>0$. However, examination failed to produce a fit for $n>0$. Therefore, the zone-refining parameters are left as "null" for this example (see Figure 6). Results calculated with the fitting macro preset parameters in Figure 6 are shown in the Summary worksheet in Software S1.

[67] In contrast to the NE Japan VF basalt, calculations with a DMM source and the Tohoku SST failed to fit the RA basalt (Chokai basalt of Kimura and Yoshida [2006]) under any conditions. The major reason is due to low slab fluid element abundances. Instead, we explored the much hotter Cascadia SST, which provides higher slab-derived element abundances due to temperature-dependent $D_{\text {mineralffluid. }}$ Use of the Cascadia SST is obviously not ideal for NE Japan; however, the overall mineralogy produced by the prograde metamorphism does not differ much from the Tohoku SST. A high slab dehydration temperature for RA basalt has been reported using ABS1 simple slab dehydration model [Kimura and Stern, 2009; Kimura and Yoshida, 2006].

[68] For the RA basalt, a 1st stage zone-refining step with $n=6$ is also necessary to accommodate deficits in $\mathrm{K}$ and $\mathrm{Rb}$ in the model basalt. This suggests that there is an additional effect of dehydration of metasomatized PERID or from reaction of the slab fluid with the metasomatized PERID. This may be reasonable for the hot slab required for the RA basalt model and the coincidence of the chlorite stability field limit at the $P-T$ condition between the two SSTs beneath the VF and RA (see Figure 1).

\subsection{ABS2 Analysis and Interpretations}

[69] Calculation results for NE Japan VF and RA basalts using ABS2 are shown in Figure 7. We here compare the new NE Japan results with our previous results and then further discuss aspects of the ABS2 model.

\subsubsection{Origin of NE Japan Basalts: VF and RA Basalts Examined by ABS2}

[70] The ABS1 results for VF basalt suggested the following inputs: source PERID was DMM depleted by $4 \%$ MORB extraction, slab SED mixing rate $r_{\text {mix }}=0.07$, slab dehydration $T_{S D S}=750^{\circ} \mathrm{C}$ and $P_{S D S}=4 \mathrm{GPa}$, mantle melting $P_{O S M}=1.0 \mathrm{GPa}, F=$ $20 \%$, and fluid mass flux $\beta=3 \mathrm{wt} \%$ [Kimura and Stern, 2009]. ABS1 constrained $\mathrm{H}_{2} \mathrm{O}$ in the mantle melting region using the experimental results of Hirose and Kawamoto [1995].

[71] The ABS2 model with its improved T-P$\mathrm{XH}_{2} \mathrm{O}-\mathrm{F}$ parameterization [Katz et al., 2003] estimates $\beta=5-12$ wt $\%$ for VF mantle melting conditions, $r_{\text {mix }}=0.07, T_{O S M}=1100$ $1350^{\circ} \mathrm{C}, P_{O S M}=1.0-2.6 \mathrm{GPa}$, and $F=19-26 \%$ with DMM source without depletion (see Figure 7). The wide $\beta$ range is the result of the relatively wide $P-T-X_{2} \mathrm{O}-\mathrm{F}$ capability accommodating various slab fluid chemistries from a range of slab dehydration conditions, from $P_{S D S}=3.4 \mathrm{GPa}, T_{S D S}=735^{\circ} \mathrm{C}$ to $5.0 \mathrm{GPa}, 810^{\circ} \mathrm{C}$. This is one of the advantages of examining all available combinations of parameters with the Fitting macro function. Weak positive correlation between $P_{O S M}$ and $T_{O S M}$ and negative correlation between $T_{O S M}$ and $\% \beta$ (Figures $7 \mathrm{c}$ and $7 \mathrm{~d}$ ) appears to originate from the melting parameterization, indicating that deep, high- $T$ mantle requires less fluid flux, whereas shallow low- $T$ mantle requires more fluid to accommodate element concentration and degree of melting in mantle melting mass balance.

[72] An interesting result for VF basalt is that different slab dehydration models do not change output much. Both Kimura and Yoshida [2006] and Kimura and Stern [2009] used simple temperature- 

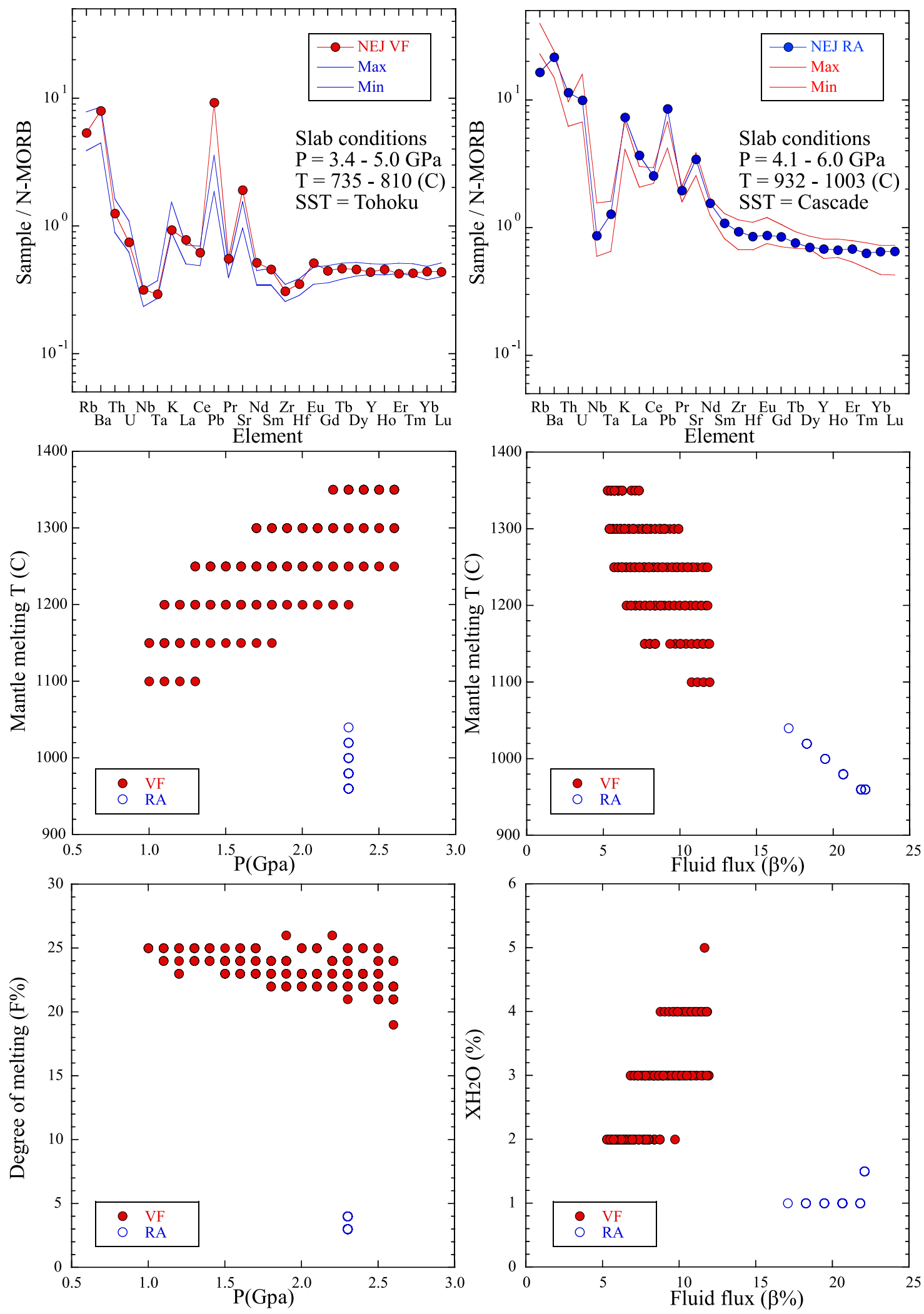

Figure 7. ABS2 results for NE Japan VF and RA basalts. Fitting result for (a) VF and (b) RA basalts with input parameters discussed in section 2. "Best fit" relationship between mantle melting temperature and (c) melting pressure and (d) fluid flux $\left(\% \beta=\% \mathrm{XH}_{2} \mathrm{O}\right.$ in primitive basalt). (e) Mantle melting pressure and $\mathrm{F}$ relation and (f) percent mantle fluid mass $\% \mathrm{XH}_{2} \mathrm{O}$ versus $\% \beta=\mathrm{H}_{2} \mathrm{O}$ in primitive basalt. See section 2 for discussion. 
dependent eclogite dehydration based on experimental results of Kessel et al. [2005a]. A poor fit was observed for $\mathrm{K}$ and $\mathrm{Rb}$ between natural VF and model basalt, due perhaps to the presence of mica in the slab, which was not considered in the previous models [Kimura and Stern, 2009; Kimura and Yoshida, 2006]. ABS2 includes phengite as a residual phase in the dehydrated slab, both for SED and AOC (see slab mineralogy table in Figure 6) and thus provides a better fit to ABS2 results except for $\mathrm{Rb}$, which may be affected by crustal contamination along with Th [Kimura and Yoshida, 2006]. Notwithstanding the different SDS models, calculated results overlap. This indicates that the slab fluid necessary for VF high $\mathrm{Mg}$ \# basalts is derived from an eclogitic source that dehydrated at $P_{S D S}=3.4-5 \mathrm{GPa}$. This depth range corresponds to a region of extensive dehydration of AOC, SED, and PERID (see Figures 3b, 3e, and 3h). This conclusion is consistent with the expectation that strong dehydration beneath the magmatic front results in greater mantle melting due to fluid fluxing [Kimura and Stern, 2009; Kimura and Yoshida, 2006].

[73] Additionally, the source PERID depletion factor $\left(\%_{M O R B}\right.$ extract $\left.=0\right)$ is smaller with ABS2 whereas $\%$ MORB extract $=4$ wt $\%$ with ABS1. The difference originates from the greater fluid addition by $\mathrm{ABS} 2$ from the parameterized fluid-fluxed mantle melting, so we think that the new conclusion is more reliable.

[74] The ABS1 results for rear-arc (RA) basalt suggested that (1) the source PERID depletion is $4 \%$ MORB extraction from DMM; (2) slab SED $r_{\text {mix }}=$ 0.03; (3) slab dehydration $T_{S D S}=1020^{\circ} \mathrm{C}$ and $P_{S D S}=6 \mathrm{GPa}$; and (4) mantle melting can be characterized by $P_{O S M}=2.3 \mathrm{GPa}, \% F=3 \%$, and fluid flux $\% \mathrm{XH}_{2} \mathrm{O}=1 \mathrm{wt} \%$ of mantle mass [Kimura and Stern, 2009]. The ABS2 results suggest that (1) PERID depletion is $0 \%$ MORB extraction from DMM; (2) $r_{\text {mix }}=0.05$; (3) $T_{S D S}=932-1003^{\circ} \mathrm{C}$ and $P_{S D S}=4.1-6.0 \mathrm{GPa}$; and (4) mantle melting $P_{O S M}=2.4 \mathrm{GPa}, \% F=3-5 \%, T_{O S M}=960-1050^{\circ} \mathrm{C}$, and $\% \mathrm{XH}_{2} \mathrm{O}=1-1.5 \%, \% \beta=15-23 \mathrm{wt} \%$ fluid in melt mass (Figure 7).

[75] In general, results from ABS1 and ABS2 models agree. These suggest that, in order to accommodate elevated LILE and LREE abundances relative to VF basalts (Figure 7), RA basalt generation requires greater slab temperatures $\left(T_{S D S}\right)$ and mantle pressures $\left(P_{O S M}\right)$, lower mantle melting fractions $\% F$ and temperature $T_{O S M}$ than those for VF basalt. The basic controls are similar to those of our ABS1 model. The RA basalt requires greater depth with lower degree of melting than in VF basalt because of the requirement of garnet in the residual mantle to achieve depletion in HREE and steeper multielement plot pattern. This results in deeper, cooler mantle beneath RA at least in the magma segregation depth. A deep magma source was suggested for the NE Japan RA by seismic tomography [Nakajima et al., 2005]. The magma production is smaller in the same RA suggesting less melting beneath RA [Kimura and Yoshida, 2006]. These evidences are the support of our model. Greater $\mathrm{H}_{2} \mathrm{O}$ contents in basaltic melt $(\% \beta=15-23 \%)$ are required by ABS2 melt modeling of RA basalt because of the requirement of low $\% \mathrm{~F}$ and high $\% \mathrm{XH}_{2} \mathrm{O}$. A major difference for the ABS2 RA basalt model is that significant stage 1 zone-refining $(n 1=5)$ is required to explain $\mathrm{Rb}$ and $\mathrm{K}$ contents. This also suggests breakdown of phengite or phlogopite at the base of the mantle wedge.

\subsubsection{Origin of NE Japan Basalts: Comparison to Previous Models}

[76] ABS2 results can be usefully compared with results from previous models for NE Japan arc magmagenesis, ABS2 estimates of slab SED/AOC contributions are similar to those proposed by previous models [Kimura and Stern, 2009; Kimura and Yoshida, 2006; Shibata and Nakamura, 1997]. Mixing ratio of released fluids from AOC and SED $\left(r_{\text {mix }}\right)$ is similar between ABS2 and previous models, notwithstanding different estimates of slab fluid composition for $\mathrm{Sr}, \mathrm{Nd}$, and $\mathrm{Pb}$ abundances based on different $D_{\text {FLUID/SLAB }}$. This may be due to the eclogitic fluid source assumed by these studies. If metamorphic minerals such as zoisite or epidote are included in slab dehydration residues, the result should have been different [Feineman et al., 2007; Green and Adam, 2003]. ABS2 model calculation confirms the absence of these minerals during slab dehydration in cold subduction zones like NE Japan. Isotope mixing calculations between slab fluid and mantle melt by open system melting does not give a much different result from those obtained by simple isotope mixing models [Sendjaja et al., 2009], although mass balance between element and isotopes is not fully maintained with the simpler models. For these reasons, the basic parameters for source components (SED, AOC, and PERID) of arc basalt do not change that much from previous models. However, these conclusions were not elucidated until the fully self-consistent mass balance ABS2 model was tested. 
[77] One major difference between previous models and $\mathrm{ABS} 2$ is $\mathrm{H}_{2} \mathrm{O}$ content in source PERID or primary basalt melt. ABS2 models $5-12$ wt \% of fluid in the primary basalt, far greater than any previous estimate for NE Japan primary magma (2-3 wt \% at maximum [Kimura and Stern, 2009; Kimura and Yoshida, 2006; Sakuyama and Nesbitt, 1986; Tatsumi et al., 1983]). The high $\mathrm{H}_{2} \mathrm{O}$ estimates by ABS2 results from the competing mass balance between trace element and degree of partial melting, as more fluid required to satisfy greater incompatible element abundance conversely increase degree of melting, resulting in dilution of fluid components by addition of PRID melt. Therefore, element abundances in the slab fluid ultimately control the ABS2 open system melting parameters. There is a large uncertainty in partition coefficient between slab and fluid. However, $\mathrm{H}_{2} \mathrm{O}$ contents in primary basalts can only be reduced by less than few times as trace element abundances in slab fluids are high (see multielement plot in Software S1 Control_Panel). Recently, $\mathrm{H}_{2} \mathrm{O}$ contents of primitive arc basalts have been estimated by various methods and may exceed $6 \mathrm{wt} \%$. This is true for lavas from both the N-Izu cold subduction zone [Hamada and Fujii, 2007; Straub and Layne, 2003] and Central America hot subduction zone [Sadofsky et al., 2008] although the water contents are still smaller than the maximum estimate of $\mathrm{H}_{2} \mathrm{O}$ near saturation in the primary basalt source [Grove et al., 2002]. With these uncertainties in mind, we think a 5-12 wt $\% \mathrm{H}_{2} \mathrm{O}$ is reasonable. Such high $\mathrm{H}_{2} \mathrm{O}$ contents in the melt source may partly result from the assumption that the entire fluid is attributed to fluid that was recently extracted from the subducted slab. Any preceding suprasubduction zone fluid-melt mantle metasomatism [Hochstaedter et al., 2001; Kimura and Yoshida, 2006; Savov et al., 2005] should reduce this parameter.

[78] The estimated degree of melting $(\% F=19-$ $26 \%$ ) is similar to the previous estimates [Kimura and Stern, 2009; Kimura and Yoshida, 2006; Tatsumi et al., 1983]. These values are far greater than the porosity estimate in the NE Japan arc estimated by seismic data [Nakajima et al., 2005]. However, our petrological model assumes local equilibrium rather than gross mantle porosity. Localized cracks for moving magma to the surface beneath the VF [Nakajima et al., 2005] could allow transport of large degree melts to the surface. We note that an estimate of mantle wedge temperature by Nakajima and Hasegawa [2003] using a seismological approach fits reasonably well with the ABS2 model, at least for the shallow level.
[79] The reliability of thermal structure models for the mantle wedge and subducted slab is an important topic [Kelemen et al., 2003a]. We applied SSTs from quantitative geodynamic models in ABS2 but did not fully use this to constrain temperatures throughout the slab. In fact, slab dehydration depth $\left(P_{S D S}\right)$, thus temperature $\left(T_{S D S}\right)$, is set as free parameter and the choice of $P_{S D S}$ controls slab fluid element concentrations via temperaturedependent partition coefficients. The observed sharp increase in SST at $\sim 3 \mathrm{GPa}$ is an important result of the latest geodynamic models. Focusing of slab dehydration is enhanced by this thermal structure. However, the stability of many hydrous, metamorphic minerals depend strongly on temperature (Figure 3), therefore, SST is more important than slab pressure. A similar discussion also applies to the necessity for high element concentrations in the RA slab fluid, because these abundances are also controlled by SST. The high SST required for RA fluid evolution reaches temperatures where the slab is likely to melt $\left(P_{S D S}=\right.$ $6 \mathrm{GPa}, T_{S D S}=\sim 1000^{\circ} \mathrm{C}$, see Figure 3). Similar suggestions that the subducted slab must melt to form N-Izu RA basalts have been proposed on the basis of trace element systematics [Hochstaedter et al., 2001; Ishizuka et al., 2003]. Slab derived liquids in the higher-pressure ranges would be melt, fluid, or supercritical fluid [Kessel et al., $2005 \mathrm{~b}]$. The features of slab derived liquid, especially phase relationships and element partitioning and SST conditions in the deeper subduction zones, should be explored by different approaches, such as experimental petrology or geophysical and geodynamic models. We hope that the results from the ABS2 model inspires further research in this field.

\subsubsection{Origin of Across-Arc Chemical and Isotopic Variations}

[80] Our ABS2 calculations suggest that the across-arc geochemical variation of NE Japan high $\mathrm{Mg} \#$ basalts originates as follows:

[81] 1. Different slab dehydration depths with different mineralogies and temperatures result in different element abundances in slab-derived fluids, producing lower LILE abundances for VF melts and greater for RA melts (see dehydration regions for VF and RA in Figure 1).

[82] 2. Mantle melting conditions differ across the arc, with higher $T_{O S M}$, higher $\% F$, shallower $P_{O S M}$, and higher fluid flux beneath the VF, compared to lower $T_{O S M}$, lower $\% F$, deeper $P_{O S M}$, and lower flux beneath the RA. All these factors contribute to 
the observed high trace element abundances in RA basalt relative to VF basalt. The depth and temperature constraints suggest a shallow origin for VF basalt generation, consistent with constraints from seismology (see Figure 1). Combined with conclusion 1, generation of VF basalt requires shallow dehydration, whereas RA basalt requires a deeper, higher- $T$ fluid. In this way, melt generation must be linked with different dehydration regions below the region of the mantle that melts (see Figure 1).

[83] 3. Significant PERID dehydration/reaction (ZR1) to yield the RA fluid is required to generate high $\mathrm{Rb}$ and $\mathrm{K}$ contents in RA basalts. This may be related to high SST, leading to the breakdown of phengite in SED and AOC and/or phlogopite in PERID (breakdown of chlorite PERID at 4-5 GPa in the mantle sole shown in Figure 1). We are not confident about this conclusion. However, this is consistent with some proposed shoshonite generation models [Edwards et al., 1991].

\section{Summary}

[84] An improved forward model that simulates the generation of primitive arc basalt magmas is presented. The Arc Basalt Simulator version 2 (ABS2) consists of a series of linked modules that sequentially calculate trace element and isotope behavior during slab dehydration (SDS), fluid-mantle zone refining (ZR1 and ZR2), and open system mantle melting (OSM) fluxed by slab-derived fluid. The element behavior during slab dehydration is formulated at $P$ and $T$, on the basis of modeled slab surface P-T trajectories (SST) and Perple_X-calculated prograde metamorphism. Mantle melting mineralogy is calculated using pMELTS for variously depleted mantle compositions. With ABS2 Excel ${ }^{\circledR}$ spreadsheet calculations, many important geochemical characteristics of arc basalts are reproduced, even though the model simplifies slab and mantle mineralogies. These results suggest that slab dehydration and fluid flux melting are the most important processes responsible for the unique chemical and isotopic compositions of primitive arc basalt magma. Intensive and extensive variables deduced from trace element mass balance ABS2 calculations suggest that the origin of across-arc geochemical variations in basalt magmas are determined by the $P-T$ conditions of slab dehydration and the conditions of mantle melting, which is controlled by fluid flux and melting $P-T$ conditions. Investigating mantle wedge $\mathrm{P}-\mathrm{T}-\mathrm{XH}_{2} \mathrm{O}$ structure is an important issue in the future, including the mode of material transfer in the system.

\section{Appendix A}

[85] Below are definitions of numbers and symbols used in the ABS version 2 Control Panel and shown in Figures 2 and 6 and sections 2 and 3 . Note that symbols used in calculations are also discussed in sections 2 and 3.

\section{A1. DENOMIN}

[86] $\mathrm{M}, \mathrm{P}$, or $\mathrm{D}$ is used to define denominator values used in multielement plots in the Control Panel. Users can alter the denominator values by replacing values for denominators in the Data Input panel. Data used are M, N-MORB [Albarède, 2005; Pearce and Parkinson, 1993]; P, primitive mantle [Sun and McDonough, 1989]; and D, DMM [Workman and Hart, 2005].

\section{A2. Predefined Model Conditions}

\section{A2.1. Sample}

[87] Given number (1-3) uses incompatible element and isotope compositions given in the Data Input panel for simulation calculations. Integers 1, 2 , or 3 are the only acceptable numbers when all data set is given in the Data_Input panel.

[88] Source compositions are as follows: $X_{S E D}$ is bulk sediment composition consisting of chert composition $\left(X_{C H}\right)$, pelagic clay composition $\left(X_{C L A Y}\right)$, and terrigeneous sediment composition $\left(X_{\text {TERR }}\right) ; X_{A O C}$ is altered oceanic crust composition; and $X_{P E R I D}$ is peridotite composition.

\section{A2.2. Slab SED Source}

[89] Numbers are mass fraction of sediment component in the slab sediment source, where $r_{S E D}$ is sediment fraction consisting of chert fraction in sediment source $\left(r_{C H}\right)$, pelagic clay fraction in sediment source $\left(r_{C L A Y}\right)$, and terrigenous sediment fraction in sediment source $\left(r_{T E R R}\right)$, where $r_{C H}+$ $r_{C L A Y}+r_{T E R R}=1$.

[90] Source sediment composition is thus expressed as

$$
X_{S E D}=r_{C H} \times X_{C H}+r_{C L A Y} \times X_{C L A Y}+r_{T E R R} \times X_{\text {TERR }} .
$$

\section{A2.3. Slab Dehydration Mode}

[91] Slab modes for slab dehydration are as follows: $X a_{S E D}=r_{C H} \times X a_{C H}+r_{C L A Y} \times X a_{C L A Y}+r_{T E R R}$ 
$r_{T E R R} \times X a_{T E R R}$ is sediment mode, $X a_{A O C}$ is altered oceanic crust mode, and $X a_{P E R I D}$ is peridotite mode (peridotite is not considered for the reason shown in section 2).

[92] Slab dehydration calculations by equation (1) (see section 2.2.3) for SED and AOC are

$X_{F L U I D}$ fluid composition of an element ( $X_{F L U I D}$ SED for SED and $X_{F L U I D}$ ${ }_{A O C}$ for AOC in Figure 2);

$X_{S L A B}$ slab composition of an element ( $X_{S E D}$ and $X_{A O C}$ in Figure 2);

$X a$ modal composition of a residual mineral in slab $\left(X a_{S E D}, X a_{A O C}\right.$ in Figure 2);

$D a$ distribution coefficient of an element between fluid and a mineral; $D_{S L A B / F L U I D}$ bulk partition coefficient between slab and fluid $\left(D_{S E D / F L U I D}\right.$, $D_{A O C / F L U I D}, D_{D M M / F L U I D}$ in Figure 2);

$F_{\text {FLUID }}$ mass fraction of fluid released from slab $\left(r_{S E D ~ H 2 O}, r_{A O C} H_{2} O\right.$ in Figure 2 where $r_{S E D ~ H 2 O}=r_{C H} H_{2 O} \times r_{C H}+$ $r_{C L A Y H 2 O} \times r_{C L A Y}+r_{T E R R ~ H 2 O} \times$ $\left.r_{\text {TERR }}\right)$.

\section{A2.4. SED Fluid Ratio}

[93] $r_{m i x}$ (section 2 and Figures 2 and 6 ) is the mass fraction of SED in slab derived fluid source defined by SED/(SED + AOC). Input values should be any number between 0 and 1. Fluid composition is derived by mixing between SED and AOC slab fluids and composition $X_{F L U I D}$ is thus redefined by

$$
X_{F L U I D}=X_{F L U I D ~ S E D} \times\left(r_{\text {mix }}\right)+X_{\text {FLUID } A O C} \times\left(1-r_{\text {mix }}\right) .
$$

\section{A2.5. Wedge PERID Source}

[94] The wedge peridotite model is chosen as follows: W, DMM composition of Workman and Hart [2005]; S, DMM composition of Salters and Stracke [2004]; I, Ichinomegata peridotite of Kimura and Yoshida [2006]; and P, primitive mantle composition of Sun and McDonough [1989].

\section{A2.6. Slab P-T Trajectory Model}

[95] The SST model is chosen for the following: I, isoviscous olivine rheology model for Izu arc; A,
Aeorian arc; T, Tohoku arc; O, temperaturedependent olivine rheology model for Izu arc; C, Cascade arc; and R, Oregon arc. Note that only the "I" model was calculated on the basis of an isoviscous model.

\section{A3. Fitting Parameters}

\section{A3.1. Slab Dehydration Temperature/ Pressure}

[96] $\mathrm{P}(\mathrm{GPa})$ is slab surface pressure in $\mathrm{GPa}$ at slab dehydration. Acceptable values are from $0.5 \mathrm{GPa}$ to $6.0 \mathrm{GPa}$ at $0.1 \mathrm{GPa}$ step. Slab surface temperature (in ${ }^{\circ} \mathrm{C}$ ) is automatically given on the basis of the SST model chosen in the predefined model conditions. Depth $(\mathrm{km})$ of the $P-T$ condition is also shown for reference.

\section{A3.2. Fluid-Mantle Reaction (Zone-Refining Model)}

[97] Degree of source peridotite (depletion) is defined by degree of melt extraction (weight percent of peridotite mass) from given wedge peridotite source defined in the predefined model conditions.

[98] $\%$ MORBext $=\%_{M O R B}$ extraction in section 2: Trace element abundances of the selected model peridotite source (W, S, I, or P) are recalculated by fractional melt extraction at given degree of melting (e.g., 10\%). Degree of melting can be set at any $0.1 \%$ step between 0 and 25 . "\%cpx mode" (weight percent) in the source is determined on the basis of source depletion guided by pMELTS calculations.

[99] The parameters $n 1$ (sole) and $n 2$ (wedge) are " $n$ " parameters in zone-refining reactions in wedge sole hydrated peridotite and anhydrous wedge peridotite, respectively. " $n$ " is defined as rock/fluid mass ratio of Ayers [1998].

[100] Symbols used for zone-refining equation (2) in section 2.3.1 are

$X_{F L U I D}$ slab fluid composition already redefined by $X_{F L U I D}=X_{F L U I D ~ S E D} \times$ $\left(r_{\text {mix }}\right)+X_{\text {FLUID AOC }} \times\left(1-r_{\text {mix }}\right)$;

$X_{\text {PERID }}^{\prime}$ metasomatized mantle peridotite composition of an element for $n 1$;

$X_{P E R I D}$ mantle peridotite composition of an element for $n 2$;

$D_{\text {PERID/FLUID }}$ partition coefficient of an element between mantle peridotite and fluid; 
$X a$ modal composition of a residual mineral in PERID;

$D a$ distribution coefficient of a mineral;

$n$ reacted mass of mantle peridotite in multiples of fluid weight, in other words, peridotite-fluid mass ratio;

$X_{\text {FLUID }}^{\prime}$ reacted fluid composition of an element after zone-refining reaction 1 ;

$X_{\text {FLUID }}^{\prime \prime}$ reacted fluid composition of an element after zone-refining reaction 2.

\section{A3.3. Fluid Flux Open System Mantle Melting}

[101] $P(\mathrm{GPa})$ is for melting condition of the open system melting between 1 and $3 \mathrm{GPa}$ at each 0.1 GPa step. $T(\mathrm{C})$ is melting temperature in ${ }^{\circ} \mathrm{C}$ for the melting condition. $\% \mathrm{XH}_{2} \mathrm{O}$ is bulk mass $\mathrm{H}_{2} \mathrm{O}$ (in wt \%) in the melting system of Katz et al. [2003].

[102] $\% F$ is percent of peridotite melting calculated on the basis of the equation of Katz et al. [2003]. $\% \beta$ is amount of $\mathrm{H}_{2} \mathrm{O}$ (fluid) mass (in weight percent) in the generated melt. Originally, $\beta$ was defined by "influx mass fraction of initial solid mass divided by degree of melting $(F)$ " [Ozawa and Shimizu, 1995] and relationship between $\beta$ and $F$ was not constrained. By combination with $\mathrm{Katz}$ et al.'s [2003] melting parameterization, $\beta$ is replaced by $\mathrm{H}_{2} \mathrm{O}$ (fluid) mass fraction in partial melt. $\% \phi$ is trapped melt fraction (wt \%) of the melting system. Note that $F, \beta$, and porosity $(\phi)$ are used as mass fraction in the open system melting calculations used in OSM and IOSM worksheets (see Software S1) and also see below.

[103] Symbols used for open system calculation equation (3) in section 2.4 are

$X_{\text {FLUID }}^{\prime \prime}$ fluid composition calculated by equation (2);

$X_{P E R I D}$ source peridotite composition;

$D_{\text {SOLID/MELT }}$ bulk melt distribution coefficient of an element;

$\mathrm{Xa}$ modal composition of a residual mineral phase;

Da melt distribution coefficient of a mineral;

$P$ contribution of consumed mineral;

$\mathrm{Pa}$ modal composition of a consumed mineral;

$\alpha$ interstitial melt fraction determined by $\alpha=\phi /(1-\phi)$; $\phi \quad$ porosity of melting system or residual melt mass fraction after melting;

$\beta$ mass fraction of fluid in generated melt which is equals to $\mathrm{XH}_{2} \mathrm{O}$ of Katz et al. [2003];

$F$ degree of partial melting;

$F c$ defined by $\alpha /(\alpha+\beta+1)$;

$X_{B A S}$ basalt melt composition of an element.

\section{Acknowledgments}

[104] We appreciate the constructive and critical comments from B. P. Roser; reviewers J. B. Gill, R. L. King, and I. Savov and three anonymous reviewers; handling editor G. Bebout; and associate editor V. Salters. This research was supported by grants-in-aid from the Ministry of Education, Science, and Culture, Japan, grants 10304038 and 12874058 to J.I.K., NSF grant OCE-0405651 to R.J.S., OCE-0646757 to P.v.K., and NSF EAR-0215641 and EAR-0545441 to B.R.H.

\section{References}

Aizawa, Y., Y. Tatsumi, and H. Yamada (1999), Element transport by dehydration of subducted sediments: Implications for arc and ocean island magmatism, Isl. Arc, 8, 38-46, doi:10.1046/j.1440-1738.1999.00217.x.

Albarède, F. (2005), The survival of mantle geochemical heterogeneities, in Earth's Deep Mantle: Structure, Composition, and Evolution, Geophys. Monogr. Ser, vol. 160, edited by R. D. van der Hilst et al., pp. 27-46, AGU, Washington, D. C.

Arculus, R. J., and R. W. Johnson (1981), Island-arc magma sources: A geochemical assessment of the roles of slabderived components and crustal contamination, Geochem. J., 15, 109-133.

Asimow, P. D., J. D. Dixon, and C. H. Langmuir (2004), A hydrous melting and fractionation model for mid-ocean ridge basalts: Application to the Mid-Atlantic Ridge near the Azores, Geochem. Geophys. Geosyst., 5, Q01E16, doi:10.1029/2003GC000568.

Ayers, J. (1998), Trace element modeling of aqueous fluid-peridotite interaction in the mantle wedge of subduction zones, Contrib. Mineral. Petrol., 132, 390-404, doi:10.1007/s004100050431.

Ayers, J. C., and E. B. Watson (1993), Rutile solubility and mobility in supercritical aqueous fluids, Contrib. Mineral. Petrol., 114, 321-330, doi:10.1007/BF01046535.

Ayers, J. C., S. K. Dittmer, and G. D. Layne (1997), Partitioning of elements between peridotite and $\mathrm{H}_{2} \mathrm{O}$ at $2.0-3.0 \mathrm{GPa}$ and $900-1100^{\circ} \mathrm{C}$, and applications to models of subduction zone processes, Earth Planet. Sci. Lett., 150, 381-398, doi:10.1016/S0012-821X(97)00096-4.

Bebout, G. E. (2007), Metamorphic chemical geodynamics of subduction zone, Earth Planet. Sci. Lett., 260, 373-393, doi:10.1016/j.eps1.2007.05.050.

Bebout, G. E., J. G. Ryan, W. P. Leeman, and A. E. Bebout (1999), Fractionation of trace elements by subduction-zone metamorphism-Effect of convergent-margin thermal evolu- 
tion, Earth Planet. Sci. Lett., 171, 63-81, doi:10.1016/ S0012-821X(99)00135-1.

Blundy, J., and B. Wood (1994), Prediction of crystal-melt partition coefficients from elastic moduli, Nature, 372, 452-454, doi:10.1038/372452a0.

Breeding, C. M., J. J. Ague, and M. Bröcker (2004), Fluidmetasedimentary rock interactions in subduction-zone mélange: Implications for the chemical composition of arc magmas, Geology, 32, 1041-1044, doi:10.1130/G20877.1.

Brenan, J. M., H. F. Shaw, F. J. Ryerson, and D. L. Phinney (1995), Mineral-aqueous fluid partitioning of trace elements at $900^{\circ} \mathrm{C}$ and $2.0 \mathrm{GPa}$ : Constraints on the trace element chemistry of mantle and deep crustal fluids, Geochim. Cosmochim. Acta, 59, 3331-3350, doi:10.1016/00167037(95)00215-L.

Carr, M. J., I. Saginor, G. E. Alvarado, L. L. Bolge, F. N. Lindsay, K. Milidakis, B. D. Turrin, M. D. Feigenson, and C. C. Swisher III (2007), Element fluxes from the volcanic front of Nicaragua and Costa Rica, Geochem. Geophys. Geosyst., 8, Q06001, doi:10.1029/2006GC001396.

Connolly, J. A. D., and D. M. Kerrick (1987), An algorithm and computer program for calculating composition phase diagrams, Calphad, 11, 1-55, doi:10.1016/03645916(87)90018-6

Connolly, J. A. D., and K. Petrini (2002), An automated strategy for calculation of phase diagram sections and retrieval of rock properties as a function of physical conditions, J. Metamorph. Geol., 20, 697-708, doi:10.1046/j. 1525-1314.2002.00398.x.

Davidson, J. P. (1996), Deciphering mantle and crustal signatures in subduction-zone magmatism, in Subduction: Top to Bottom, Geophys. Monogr. Ser., vol. 96, edited by G. E. Bebout et al., pp. 251-262, AGU, Washington, D. C.

Defant, M. J., and M. S. Drummond (1990), Derivation of some modern arc magmas by melting of young subducted lithosphere, Nature, 347, 662-665, doi:10.1038/347662a0.

Edwards, C. M. H., M. A. Menzies, and M. F. Thirlwall (1991), Evidence from Muriah, Indonesia, for the interplay of suprasubduction zone and intraplate processes in the genesis of potassic alkaline magmas, J. Petrol., 32, 555-592.

Eiler, J. M., M. J. Carr, M. Reagan, and E. M. Stolper (2005), Oxygen isotope constraints on the sources of Central American arc lavas, Geochem. Geophys. Geosyst., 6, Q07007, doi:10.1029/2004GC000804.

Eiler, J. M., P. Schiano, J. M. Valley, N. T. Kita, and E. M. Stolper (2007), Oxygen-isotope and trace element constraints on the origins of silica-rich melts in the subarc mantle, Geochem. Geophys. Geosyst., 8, Q09012, doi:10.1029/ 2006GC001503.

Elburg, M., M. van Bergen, J. Hoogewerff, J. Foden, P. Vroon, I. Zurkarnain, and A. Nasution (2002), Geochemical trends across an arc-continent collision zone: Magma sources and slab-wedge transfer processes below the Pantar Strait volcanoes, Indonesia, Geochim. Cosmochim. Acta, 66, 27712789, doi:10.1016/S0016-7037(02)00868-2.

Elburg, M. A., T. van Leeuwen, J. Foden, and Muhardjo (2003), Spatial and temporal isotopic domains of constraining igneous suites in Western and Northern Sulawesi, Indonesia, Chem. Geol., 199, 243-276.

Elliott, T., T. Plank, A. Zindler, W. White, and B. Bourdon (1997), Element transport from slab to volcanic front at the Mariana arc, J. Geophys. Res., 102(B7), 14,991-15,019, doi:10.1029/97JB00788.

Faure, G., and T. M. Mensing (2005), Isotopes Principles and Applications, 896 pp., John Wiley, Hoboken, N. J.
Feineman, M. D., F. J. Ryerson, D. J. DePaolo, and T. Plank (2007), Zoisite-aqueous fluid trace element partitioning with implications for subduction zone fluid composition, Chem. Geol., 239, 250-265, doi:10.1016/j.chemgeo.2007.01.008.

Foden, J. D., and D. H. Green (1992), Possible role of amphibole in the origin of andesite: Some experimental and natural evidence, Contrib. Mineral. Petrol., 109, 479-493, doi:10.1007/BF00306551.

Gao, J., T. John, R. Klemd, and X. Xiong (2007), Mobilization of Ti-Nb-Ta during subduction: Evidence from rutile-bearing dehydration segregations and veins hosted in eclogite, Tianshan, NW, China, Geochim. Cosmochim. Acta, 71, 49744996, doi:10.1016/j.gca.2007.07.027.

Garrido, C. J., V. L. Sanchez-Vizcaino, M. T. Gomez-Pugnaire, V. Trommsdorff, O. Alard, J.-L. Bodinier, and M. Godard (2005), Enrichment of HFSE in chlorite-harzburgite produced by high-pressure dehydration of antigorite-serpentinite: Implications for subduction magmatism, Geochem. Geophys. Geosyst., 6, Q01J15, doi:10.1029/2004GC000791.

Ghiorso, M. S., M. M. Hirschmann, P. W. Reiners, and V. C. Kress (2002), The pMELTS: A revision of MELTS for improved calculation of phase relations and major element partitioning related to partial melting of the mantle to $3 \mathrm{GPa}$, Geochem. Geophys. Geosyst., 3(5), 1030, doi:10.1029/ $2001 \mathrm{GC} 000217$

Gill, J. B. (1981), Orogenic Andesites and Plate Tectonics, 385 pp., Springer, Heiderberg, Germany.

Green, D. H. (1973), Contrasted melting regions in a pyrolite upper mantle under mid-oceanic ridge, stable crust and island arc environments, Tectonophysics, 17, 285-297, doi:10.1016/0040-1951(73)90008-5.

Green, T. H. (1994), Experimental studies of trace-element partitioning applicable to igneous petrogenesis-Sedona 16 years later, Chem. Geol., 117, 1-36, doi:10.1016/00092541(94)90119-8.

Green, T. H. (1995), Significance of $\mathrm{Nb} / \mathrm{Ta}$ as an indicator of geochemical processes in the crust-mantle system, Chem. Geol., 120, 347-359, doi:10.1016/0009-2541(94)00145-X.

Green, T. H., and J. Adam (2003), Experimentally determined trace element characteristics of aqueous fluid from partially dehydrated mafic oceanic crust at $3.0 \mathrm{GPa}, 650-700^{\circ} \mathrm{C}$, Eur. J. Mineral., 15, 815-830, doi:10.1127/0935-1221/2003/ 0015-0815.

Green, T. H., J. D. Blundy, J. Adam, and G. M. Yaxley (2000), SIMS determination of trace element partition coefficients between garnet, clinopyroxene and hydrous basaltic liquids at $2-7.5 \mathrm{GPa}$ and $1080-1200^{\circ} \mathrm{C}$, Lithos, 53, 165-187, doi:10.1016/S0024-4937(00)00023-2.

Grove, T. L., S. W. Parman, S. A. Bowring, R. C. Price, and M. B. Baker (2002), The role of an $\mathrm{H}_{2} \mathrm{O}$-rich fluid component in the generation of primitive basaltic andesites and andesites from the Mt. Shasta region, N California, Contrib. Mineral. Petrol., 142, 375-396.

Grove, T. L., N. Chatterjee, S. W. Parman, and E. Medard (2006), The influence of $\mathrm{H}_{2} \mathrm{O}$ on mantle wedge melting, Earth Planet. Sci. Lett., 249, 74-89, doi:10.1016/ j.epsl.2006.06.043.

Hacker, B. R. (2008), $\mathrm{H}_{2} \mathrm{O}$ subduction beyond arcs, Geochem. Geophys. Geosyst., 9, Q03001, doi:10.1029/2007GC001707.

Hamada, M., and T. Fujii (2007), $\mathrm{H}_{2} \mathrm{O}$-rich island arc low-K tholeiite magma inferred from Ca-rich plagioclase-melt inclusion equilibria, Geochem. J., 41, 437-461.

Hasegawa, A., D. Zhao, S. Hori, A. Yamamoto, and S. Horiuchi (1991), Deep structure of the northeastern Japan arc and its relationship to seismic and volcanic activity, Nature, 352, 683-689, doi:10.1038/352683a0. 
Hauff, F., K. Hoernle, and A. Schmidt (2003), Sr-Nd-Pb composition of Mesozoic Pacific oceanic crust (Site 1149 and 801, ODP Leg 185): Implications for alteration of ocean crust and the input into the Izu-Bonin-Mariana subduction system, Geochem. Geophys. Geosyst., 4(8), 8913, doi:10.1029/2002GC000421.

Hawkesworth, C. J., K. Gallagher, J. M. Hergt, and F. McDermott (1993), Trace element fractionation processes in the generation of island arc basalts, Philos. Trans. R. Soc. London, Ser. A, 342, 179-191, doi:10.1098/rsta.1993.0013.

Hirose, K., and T. Kawamoto (1995), Hydrous partial melting of lherzolite at $1 \mathrm{Gpa}$ : The effect of $\mathrm{H}_{2} \mathrm{O}$ on the genesis of basaltic magmas, Earth Planet. Sci. Lett., 133, 463-473, doi:10.1016/0012-821X(95)00096-U.

Hochstaedter, A., J. Gill, R. Peters, P. Broughton, P. Holden, and B. Taylor (2001), Across-arc geochemical trends in the Izu-Bonin arc: Contributions from the subducting slab, Geochem. Geophys. Geosyst., 2(7), 1019, doi:10.1029/ 2000GC000105.

Ionov, D. A., and A. W. Hofmann (1995), Nb-Ta-rich mantle amphiboles and micas: Implications for subduction-related metasomatic trace element fractionations, Earth Planet. Sci. Lett., 131, 341-356, doi:10.1016/0012-821X(95) 00037-D.

Ishikawa, T., and E. Nakamura (1994), Origin of the slab component in arc lavas from across-arc variation of $\mathrm{B}$ and $\mathrm{Pb}$ isotopes, Nature, 370, 205-208, doi:10.1038/370205a0.

Ishikawa, T., and F. Tera (1999), Two isotopically distinct fluid components involved in the Mariana Arc: Evidence from $\mathrm{Nb} / \mathrm{B}$ ratios and $\mathrm{B}, \mathrm{Sr}, \mathrm{Nd}$, and $\mathrm{Pb}$ isotope systematics, Geology, 27, 83-86, doi:10.1130/0091-7613(1999)027< 0083:TIDFCI $>2.3 . \mathrm{CO} ; 2$.

Ishizuka, O., R. N. Taylor, J. A. Milton, and R. W. Nesbitt (2003), Fluid-mantle interaction in an intra-oceanic arc: Constraints from high-precision $\mathrm{Pb}$ isotopes, Earth Planet. Sci. Lett., 211, 221-236, doi:10.1016/S0012-821X(03)00201-2.

Ishizuka, O., R. N. Taylor, J. A. Milton, R. E. Nesbitt, M. Yuasa, and I. Sakamoto (2006), Variation in the mantle sources of the northern Izu arc with time and space - Constraints from high-precision $\mathrm{Pb}$ isotopes, J. Volcanol. Geotherm. Res., 156, 266-290, doi:10.1016/j.jvolgeores.2006.03.005.

Iwamori, H. (1998), Transport of $\mathrm{H}_{2} \mathrm{O}$ in subduction zones, Earth Planet. Sci. Lett., 160, 65-80, doi:10.1016/S0012821X(98)00080-6.

Iwamori, H. (2000), Deep subduction of $\mathrm{H}_{2} \mathrm{O}$ and deflection of volcanic chain towards backarc near triple junction due to lower temperature, Earth Planet. Sci. Lett., 181, 41-46, doi:10.1016/S0012-821X(00)00180-1.

Johnson, M. C., and T. Plank (1999), Dehydration and melting experiments constrain the fate of subducted sediments, Geochem. Geophys. Geosyst., 1(12), 1007, doi:10.1029/ 1999GC000014.

Katz, R. F., M. Spiegelman, and C. H. Langmuir (2003), A new parameterization of hydrous mantle melting, Geochem. Geophys. Geosyst., 4(9), 1073, doi:10.1029/2002GC000433.

Kelemen, P. B., S. R. Hart, and S. Bernstein (1998), Silica enrichment in the continental upper mantle via melt/rock reaction, Earth Planet. Sci. Lett., 164, 387-406, doi:10.1016/S0012-821X(98)00233-7.

Kelemen, P. B., J. L. Rilling, E. M. Parmentier, L. Mehl, and B. R. Hacker (2003a), Thermal structure due to solid-state flow in the mantle wedge beneath arcs, in Inside the Subduction Factory, Geophys. Monogr. Ser, vol. 138, edited by J. Eiler, pp. 293-311, AGU, Washington, D. C.

Kelemen, P. B., G. M. Yogodzinski, and D. W. Scholl (2003b), Along-strike variation in the Aleutian island arc: Genesis of high $\mathrm{Mg} \#$ andesite and implications for continental crust, in Inside the Subduction Factory, Geophys. Monogr. Ser, vol. 138, edited by J. M. Eiler, pp. 223-276, AGU, Washington, D. C.

Kelley, K. A., T. Plank, J. Ludden, and H. Staudigel (2003), Composition of altered oceanic crust at ODP Sites 801 and 1149, Geochem. Geophys. Geosyst., 4(6), 8910, doi:10.1029/ 2002GC000435.

Kelley, K. A., T. Plank, T. L. Grove, E. M. Stolper, S. Newman, and E. Hauri (2006), Mantle melting as a function of water content beneath back-arc basins, J. Geophys. Res., 111, B09208, doi:10.1029/2005JB003732.

Kersting, A. B., R. J. Arculus, and D. A. Gust (1996), Lithospheric contributions to arc magmatism: Isotope variations along strike in volcanoes of Honshu, Japan, Science, 272, 1464-1468, doi:10.1126/science.272.5267.1464.

Kessel, R., M. W. Schmidt, P. Ulmer, and T. Pettke (2005a), Trace element signature of subduction-zone fluids, melts and supercritical liquids at 120-180 km depth, Nature, 437, $724-727$.

Kessel, R., P. Ulmer, T. Pettke, M. W. Schmidt, and A. B. Thompson (2005b), The water-basalt system at 4 to $6 \mathrm{GPa}$ : Phase relations and second critical endpoint in a K-free eclogite at 700 to $1400^{\circ} \mathrm{C}$, Earth Planet. Sci. Lett., 237, $873-$ 892, doi:10.1016/j.epsl.2005.06.018.

Kimura, J.-I., and R. J. Stern (2009), Neogene volcanism of the Japan island arc: The K-h relationship revisited, in CircumPacific Tectonics, Geologic Evolution, and Ore Deposits, Ariz. Geol. Soc. Dig., vol. 22, pp., 187-202, Ariz. Geol. Soc., Tucson.

Kimura, J.-I., and T. Yoshida (2006), Contributions of slab fluid, mantle wedge and crust to the origin of Quaternary lavas in the NE Japan arc, J. Petrol., 47, 2185-2232, doi:10.1093/petrology/eg1041.

Kimura, J.-I., R. J. Stern, and T. Yoshida (2005), Re-initiation of subduction and magmatic responses in SW Japan during Neogene time, Geol. Soc. Am. Bull., 117, 969-986, doi:10.1130/B25565.1.

Kimura, J.-I., T. W. Sisson, N. Nakano, M. L. Coombs, and P. W. Lipman (2006), Geochemistry of early Kilauea magmas from the submarine Hilina bench: The nature of the Hilina mantle component, J. Volcanol. Geotherm. Res., 151, 51-72, doi:10.1016/j.jvolgeores.2005.07.024.

King, R. L., M. J. Kohn, and J. M. Eiler (2003), Constraints on the petrologic structure of the subduction zone slab-mantle interface from Franciscan Complex exotic ultramafic blocks, Geol. Soc. Am. Bull., 115, 1097-1109, doi:10.1130/ B25255.1.

King, R. L., G. E. Bebout, T. Moriguti, and E. Nakamura (2006), Element mixing systematics and Sr-Nd isotope geochemistry of mélange formation: Obstacles to identification of fluid sources to arc volcanics, Earth Planet. Sci. Lett., 246, 288-304, doi:10.1016/j.eps1.2006.03.053.

King, R. L., G. E. Bebout, M. Grove, T. Moriguti, and E. Nakamura (2007), Boron and lead isotope signatures of subduction-zone mélange formation: Hybridization and fractionation along the slab-mantle interface beneath volcanic arcs, Chem. Geol., 239, 305-322, doi:10.1016/j.chemgeo. 2007.01.009.

Kneller, E. A., P. E. van Keken, I. Katayama, and S. Karato (2007), Stress, strain and B-type olivine fabric in the fore-arc mantle: Sensitivity tests using high-resolution steady state subduction zone models, J. Geophys. Res., 112, B04406, doi:10.1029/2006JB004544.

Kogiso, T., Y. Tatsumi, and S. Nakano (1997), Trace element transport during dehydration processes in the subducted 
oceanic crust: 1. Experiments and implications for the origin of oceanic island basalts, Earth Planet. Sci. Lett., 148, $193-$ 205, doi:10.1016/S0012-821X(97)00018-6.

Kushiro, I. (1996), Partial melting of a fertile mantle peridotite at high pressures: An experimental study using aggregates of diamond, in Earth Processes: Reading the Isotopic Code, Geophys. Monogr. Ser., vol. 95, edited by A. Basu and S. Hart, pp. 109-122, AGU, Washington, D. C.

Manning, C. E. (2004), The chemistry of subduction-zone fluids, Earth Planet. Sci. Lett., 223, 1-16, doi:10.1016/ j.epsl.2004.04.030.

Marschall, H. R., R. Altherr, T. Ludwig, A. Kalt, K. Gméling, and Z. Kasztovszky (2006), Partitioning and budget of Li, $\mathrm{Be}$ and $\mathrm{B}$ in high-pressure metamorphic rocks, Geochim. Cosmochim. Acta, 70, 4750-4769, doi:10.1016/j.gca.2006. 07.006 .

Marschall, H. R., R. Altherr, and L. Rüpke (2007), Squeezing out the slab-Modeling the release of $\mathrm{Li}, \mathrm{Be}$, and $\mathrm{B}$ during progressive high-pressure metasomatism, Chem. Geol., 239, 323-335, doi:10.1016/j.chemgeo.2006.08.008

Martin, H. (1999), Adakitic magmas: Modern analogues of Archaean granitoids, Lithos, 46, 411-429, doi:10.1016/ S0024-4937(98)00076-0.

Martin, H., R. H. Smithies, R. Rapp, J.-F. Moyen, and D. Champion (2005), An overview of adakite, tonalitetrondhjemite-granodiorite (TTG), and sanukitoid: Relationships and some implications for crustal evolution, Lithos, 79, 1-24, doi:10.1016/j.lithos.2004.04.048.

McCulloch, M. T., and J. A. Gamble (1991), Geochemical and geodynamical constraints on subduction-zone magmatism, Earth Planet. Sci. Lett., 102, 358-374, doi:10.1016/0012821X(91)90029-H.

McDade, P., J. D. Blundy, and B. J. Wood (2003a), Trace element partitioning between mantle wedge peridotite and hydrous MgO-rich melt, Am. Mineral., 88, 1825-1831.

McDade, P., J. D. Blundy, and B. J. Wood (2003b), Trace element partitioning on the Tinaquillo lherzolite solidus at 1.5 GPa, Phys. Earth Planet. Inter., 139, 129-147, doi:10.1016/S0031-9201(03)00149-3.

Moriguti, T., T. Shibata, and E. Nakamura (2004), Lithium, boron and lead isotope and trace element systematics of Quaternary basaltic volcanic rocks in northeastern Japan: Mineralogical controls on slab-derived fluid composition, Chem. Geol., 212, 81-100, doi:10.1016/j.chemgeo.2004. 08.005 .

Nakajima, J., and A. Hasegawa (2003), Estimation of thermal structure in the mantle wedge of northeastern Japan from seismic attenuation data, Geophys. Res. Lett., 30(14), 1760, doi:10.1029/2003GL017185.

Nakajima, J., Y. Takei, and A. Hasegawa (2005), Quantitative analysis of the inclined low-velocity zone in the mantle wedge of northern Japan: A systematic change of melt-filled pore shapes with depth and its implications for melt migration, Earth Planet. Sci. Lett., 234, 59-70, doi:10.1016/ j.eps1.2005.02.033.

Navon, O., and E. Stolper (1987), Geochemical consequence of melt percolation: The upper mantle as a chromatographic column, J. Geol., 95, 285-307.

Navon, O., F. A. Frey, and E. Takazawa (1996), Magma transport and metasomatism in the mantle: A critical review of current geochemical models-Discussion, Am. Mineral., 81, $754-759$.

Ozawa, K. (2001), Mass balance equations for open magmatic systems: Trace element behavior and its application to open system melting in the upper mantle, J. Geophys. Res., 106, 13,407-13,434, doi:10.1029/2001JB900001.
Ozawa, K., and N. Shimizu (1995), Open-system melting in the upper mantle: Constraints from the Hayachine-Miyamori ophiolite, northeastern Japan, J. Geophys. Res., 100, 22,315-22,335, doi:10.1029/95JB01967.

Peacock, S. M., and K. Wang (1999), Seismic consequence of warm versus cool subduction metamorphism: Examples from southwest and northeast Japan, Science, 286, $937-$ 939, doi:10.1126/science.286.5441.937.

Peacock, S. M., P. E. van Keken, S. D. Hollowey, B. R. Hacker, G. A. Abers, and R. L. Fergason (2005), Thermal structure of the Costa Rica-Nicaragua subduction zone, Phys. Earth Planet. Inter., 149, 187-200, doi:10.1016/j.pepi.2004. 08.030.

Pearce, J. A., and I. J. Parkinson (1993), Trace element models for mantle melting: Application to volcanic arc petrogenesis, in Magmatic Processes and Plate Tectonics, edited by H. M. Prichard et al., Geol. Soc. Spec. Publ., 76, 373-403.

Pearce, J. A., and D. W. Peate (1995), Tectonic implications of the composition of volcanic arc magmas, Annu. Rev. Earth Planet. Sci., 23, 251-285, doi:10.1146/annurev.ea.23. 050195.001343.

Pearce, J. A., R. J. Stern, S. H. Bloomer, and P. Fryer (2005), Geochemical mapping of the Mariana arc-basin system: Implications for the nature and distribution of subduction components, Geochem. Geophys. Geosyst., 6, Q07006, doi:10.1029/2004GC000895.

Plank, T., and C. H. Langmuir (1993), Tracing trace elements from sediment input to volcanic output at subduction zones, Nature, 362, 739-742, doi:10.1038/362739a0.

Plank, T., and C. H. Langmuir (1998), The chemical composition of subducting sediment and its consequence for the crust and mantle, Chem. Geol., 145, 325-394, doi:10.1016/ S0009-2541(97)00150-2.

Poli, S., and M. W. Schmidt (1995), $\mathrm{H}_{2} \mathrm{O}$ transport and release in subduction zones: Experimental constraints on basaltic and andesitic systems J. Geophys. Res., 100(B11), 22,29922,314, doi:10.1029/95JB01570.

Rapp, E. P., and E. B. Watson (1995), Dehydration melting of metabasalt at 8-32 kbar: Implications for continental growth and crustal-mantle recycling, J. Petrol., 36, 891-931.

Ryan, J. G., J. Morris, F. Tera, W. P. Leeman, and A. Tsvetkov (1995), Cross-arc geochemical variations in the Kurile Arc as a function of slab depth, Science, 270, 625-627, doi:10.1126/science.270.5236.625

Sadofsky, S. J., M. Portnyagin, K. Hoernle, and P. van den Bogaard (2008), Subduction cycling of volatiles and trace elements through the Central American volcanic arc: Evidence from melt inclusions, Contrib. Mineral. Petrol., 155, 433-456, doi:10.1007/s00410-007-0251-3.

Sajona, F. G., R. C. Maury, H. Bellon, J. Cotten, and M. Defant (1996), High field strength element enrichment of Pliocene-Pleistocene island arc basalts, Zamboanga Peninsula, western Mindanao (Philippines), J. Petrol., 37, 693726, doi:10.1093/petrology/37.3.693.

Sakuyama, M., and R. W. Nesbitt (1986), Geochemistry of the Quaternary volcanic rocks of the northeast Japan arc, J. Volcanol. Geotherm. Res., 29, 413-450, doi:10.1016/ 0377-0273(86)90053-3.

Salters, V. M., and A. Stracke (2004), Composition of the depleted mantle, Geochem. Geophys. Geosyst., 5, Q05B07, doi:10.1029/2003GC000597.

Salters, V. J. M., J. E. Longhi, and M. Bizimis (2002), Near mantle solidus trace element partitioning at pressures up to $3.4 \mathrm{GPa}$, Geochem. Geophys. Geosyst., 3(7), 1038, doi:10.1029/2001GC000148. 
Savov, I. P., J. G. Ryan, M. D’Antonio, K. Kelley, and P. Mattie (2005), Geochemistry of serpentinized peridotites from the Mariana Forearc Conical Seamount, ODP Leg 125: Implications for the elemental recycling at subduction zones, Geochem. Geophys. Geosyst., 6, Q04J15, doi:10.1029/ 2004GC000777.

Schmidt, M. W., and S. Poli (1998), Experimentally based water budget for dehydrating slabs and consequences for arc magma generation, Earth Planet. Sci. Lett., 163, 361379, doi:10.1016/S0012-821X(98)00142-3.

Schmidt, M. W., D. Vielzeuf, and E. Auzanneau (2004), Melting and dissolution of subducting crust at high pressures: The key role of white mica, Earth Planet. Sci. Lett., 228, 65-84, doi:10.1016/j.eps1.2004.09.020.

Sen, C., and T. Dunn (1994), Dehydration melting of a basaltic composition amphibolite at 1.5 and $2.0 \mathrm{GPa}$ : Implications for the origin of adakites, Contrib. Mineral. Petrol., 117, 394409, doi:10.1007/BF00307273.

Sendjaja, Y. A., J.-I. Kimura, and E. Sunardi (2009), Acrossarc geochemical variation of Quaternary lavas in West Java, Indonesia: Mass-balance elucidation using Arc Basalt Simulator model, Isl. Arc, 18, 201-224, doi:10.1111/j.14401738.2008.00641.x.

Shaw, D. M. (2000), Continuous (dynamic) melting theory revisited, Can. Mineral., 38, 1041-1063, doi:10.2113/ gscanmin.38.5.1041.

Shibata, T., and E. Nakamura (1997), Across-arc variations of isotope and trace element compositions from Quaternary basaltic rocks in northeastern Japan: Implications for interaction between subducted oceanic slab and mantle wedge, J. Geophys. Res., 102(B4), 8051-8064, doi:10.1029/ 96JB03661.

Shimoda, G., and S. Nohda (1995), Lead isotope analyses: An application to GSJ standard rock samples, Human Environ. Stud., 4, 29-36.

Smith, P. M., and P. D. Asimow (2005), Adiabat 1ph: A new public front-end to the MELTS, pMELTS, and pHMELTS models, Geochem. Geophys. Geosyst., 6, Q02004, doi:10.1029/2004GC000816.

Spandler, C., J. Hermann, R. Arculus, and J. Mavrogenes (2004), Geochemical heterogeneity and element mobility in deeply subducted oceanic crust: Insights from high-pressure mafic rocks from New Caledonia, Chem. Geol., 206, 21-42, doi:10.1016/j.chemgeo.2004.01.006.

Stalder, R., S. F. Foley, G. P. Brey, and I. Horn (1998), Mineralaqueous fluid partitioning of trace elements at $900-1200^{\circ} \mathrm{C}$ and 3.0-5.7 GPa: New experimental data for garnet, clinopyroxene, and rutile, and implications for mantle metasomatism, Geochim. Cosmochim. Acta, 62, 1781-1801, doi:10.1016/S0016-7037(98)00101-X.

Staudigel, H., T. Plank, B. White, and H.-U. Schmincke (1996), Geochemical fluxes during seafloor alteration of the basaltic upper crust: DSDP Sites 417 and 418, in Subduction: Top to Bottom, Geophys. Monogr. Ser., vol. 96, edited by G. E. Bebout et al., pp. 19-38, AGU, Washington, D. C.

Stern, R. J. (2002), Subduction zones, Rev. Geophys., 40(4), 1012, doi:10.1029/2001RG000108

Stern, R. J., M. J. Fouch, and S. L. Klemperer (2003), An overview of the Izu-Bonin-Mariana subduction factory, in Inside the Subduction Factory, Geophys. Monogr. Ser, vol. 138, edited by J. Eiler, pp. 175-222, AGU, Washington, D. C.

Stolper, E. M., and S. Newman (1994), The role of water in the petrogenesis of Mariana trough magmas, Earth Planet. Sci. Lett., 121, 293-325, doi:10.1016/0012-821X(94)90074-4.
Straub, S. M., and G. D. Layne (2003), The systematics of chlorine, fluorine, and water in Izu arc front volcanic rocks: Implications for volatile recycling in subduction zones, Geochim. Cosmochim. Acta, 67(21), 4179-4203, doi:10.1016/S0016-7037(03)00307-7.

Straub, S. M., A. B. LaGatta, A. L. Martin-DelPozzo, and C. H. Langmuir (2008), Evidence from high-Ni olivines for a hybridized peridotite/pyroxenite source for orogenic andesites from the central Mexican Volcanic Belt, Geochem Geophys. Geosyst., 9, Q03007, doi:10.1029/2007GC001583.

Sun, S., and W. F. McDonough (1989), Chemical and isotopic systematics of oceanic basalts: Implications for mantle composition and processes, Geol. Soc. Spec. Publ., 42, 313-345.

Tatsumi, Y., and S. Eggins (1995), Subduction-Zone Magmatism, 211 pp., Blackwell Sci., Cambridge, Mass.

Tatsumi, Y., and T. Hanyu (2003), Geochemical modeling of dehydration and partial melting of subducting lithosphere: Toward a comprehensive understanding of high-Mg andesite formation in the Setouchi volcanic belt, SW Japan, Geochem. Geophys. Geosyst., 4(9), 1081, doi:10.1029/ 2003GC000530.

Tatsumi, Y., M. Sakuyama, H. Fukuyama, and I. Kushiro (1983), Generation of basaltic magmas and thermal structure of the mantle wedge in subduction zone, J. Geophys. Res., 88, 5815-5825, doi:10.1029/JB088iB07p05815.

Taylor, B., and F. Martinez (2003), Back-arc basin basalt systematics, Earth Planet. Sci. Lett., 210, 1-17.

Taylor, S. R., and S. M. McLennan (1985), The Continental Crust: Its Composition and Evolution, 312 pp., Blackwell Sci., Oxford, U. K.

Tollstrup, D. L., and J. B. Gill (2005), Hafnium systematics of the Mariana arc: Evidence for sediment melt and residual phases, Geology, 33, 737-740, doi:10.1130/G21639.21631.

Tsuchiya, N., S. Suzuki, J.-I. Kimura, and H. Kagami (2005), Evidence for slabmelt/mantle reaction: Petrogenesis of Early Cretaceous and Eocene high-Mg andesites from the Kitakami Mountains, Japan, Lithos, 79, 179-206, doi:10.1016/ j.lithos.2004.04.053.

Tsuchiya, N., J.-I. Kimura, and H. Kagami (2007), Petrogenesis of Early Cretaceous adakitic granites from the Kitakami Mountains, Japan, J. Volcanol. Geotherm. Res., 167, 134159, doi:10.1016/j.jvolgeores.2007.07.002.

Turner, S., and J. Foden (2001), U, Th and Ra disequilibria, Sr, $\mathrm{Nd}$, and $\mathrm{Pb}$ isotope and trace element variations in Sunda arc lavas: Predominance of a subducted sediment component, Contrib. Mineral. Petrol., 142, 43-57.

Turner, S., C. J. Hawkesworth, N. Rogers, J. Bartlett, T. Worthington, J. Hergt, J. A. Pearce, and I. M. E. Smith (1997), ${ }^{238} \mathrm{U}_{-}{ }^{230} \mathrm{Th}$ disequilibria, magma petrogenesis, and flux rates beneath the depleted Tonga-Kermadec island arc, Geochim. Cosmochim. Acta, 61, 4855-4884, doi:10.1016/ S0016-7037(97)00281-0.

Usui, T., K. Kobayashi, E. Nakamura, and H. Helmstaedt (2007), Trace element fractionation in deep subduction zones inferred from a lawsonite-eclogite xenolith from the Colorado Plateau, Chem. Geol., 239, 336-351, doi:10.1016/ j.chemgeo.2006.08.009.

van Keken, P. E. (2003), The structure and dynamics of the mantle wedge, Earth Planet. Sci. Lett., 215, 323-338, doi:10.1016/S0012-821X(03)00460-6.

van Keken, P. E., B. Kiefer, and S. M. Peacock (2002), Highresolution models of subduction zones: Implications for mineral dehydration reactions and the transport of water into the deep mantle, Geochem. Geophys. Geosyst., 3(10), 1056, doi:10.1029/2001GC000256. 
van Westrenen, W., and D. S. Draper (2007), Quantifying garnet-melt trace element partitioning using lattice-strain theory: New crystal-chemical and thermodynamic constraints, Contrib. Mineral. Petrol., 154, 717-730, doi:10.1007/s00410-007-0222-8.

Verniéres, J., M. Godard, and J. L. Bodinier (1997), A plate model for the simulation of trace element fractionation during partial melting and magma transport in the Earth's upper mantle, J. Geophys. Res., 102, 24,771-24,784, doi:10.1029/ 97JB01946.

Wilson, M. (1989), Igneous Petrogenesis: A Global Tectonic Approach, 466 pp., Unwin Hyman, London.

Workman, R. K., and S. R. Hart (2005), Major and trace element composition of the depleted MORB mantle (DMM), Earth Planet. Sci. Lett., 231, 53-72, doi:10.1016/ j.eps1.2004.12.005.

Wunder, B., A. Meixner, R. L. Romer, R. Wirth, and W. Heinlich (2005), The geochemical cycle of boron: Constraints from boron isotope partitioning experiments between mica and fluid, Lithos, 84, 206-216, doi:10.1016/ j.lithos.2005.02.003.
Wunder, B., A. Meixner, R. L. Romer, and W. Heinrich (2006), Temperature-dependent isotopic fractionation of lithium between clinopyroxene and high-pressure hydrous fluids, Contrib. Mineral. Petrol., 151, 112-120, doi:10.1007/ s00410-005-0049-0.

Yogodzinski, G. M., O. N. Volynets, A. V. Koloskov, N. I. Seliverstov, and V. V. Matvenkov (1994), Magnesian andesites and the subduction component in a strongly calcalkaline series at the Piip volcano, far Western Aleutian, J. Petrol., 35, 163-204.

Zack, T., S. F. Foley, and T. Rivers (2002), Equilibrium and disequilibrium trace element partitioning in hydrous eclogites (Trescolmen, central Alps), J. Petrol., 43, 19471974, doi:10.1093/petrology/43.10.1947.

Zou, H. (1998), Trace element fractionation during modal and nonmodal dynamic melting and open-system melting: A mathematical treatment, Geochim. Cosmochim. Acta, 62, 1937-1945, doi:10.1016/S0016-7037(98)00115-X. (Erratum, Geochim. Cosmochim. Acta, 63, 2695, doi:10.1016/S00167037(99)00055-1, 1999.) 